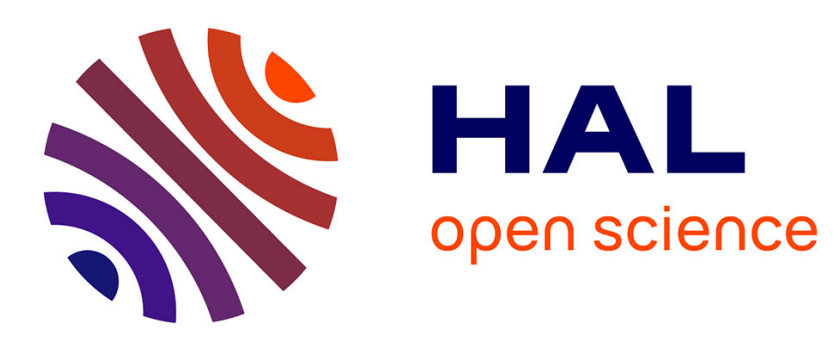

\title{
Export promotion programs, export capabilities, and risk management practices of internationalized SMEs
}

\author{
Alexis Catanzaro, Christine Teyssier
}

\section{To cite this version:}

Alexis Catanzaro, Christine Teyssier. Export promotion programs, export capabilities, and risk management practices of internationalized SMEs. Small Business Economics, inPress, 10.1007/s11187020-00358-4 . hal-03034452

\section{HAL Id: hal-03034452 \\ https://hal.science/hal-03034452}

Submitted on 9 Dec 2020

HAL is a multi-disciplinary open access archive for the deposit and dissemination of scientific research documents, whether they are published or not. The documents may come from teaching and research institutions in France or abroad, or from public or private research centers.
L'archive ouverte pluridisciplinaire HAL, est destinée au dépôt et à la diffusion de documents scientifiques de niveau recherche, publiés ou non, émanant des établissements d'enseignement et de recherche français ou étrangers, des laboratoires publics ou privés. 


\title{
Export Promotion Programs, Export Capabilities and Risk Management Practices of Internationalized SMEs
}

\author{
Alexis Catanzaro \\ Jean Monnet University - Coactis - Labex Entreprendre \\ Christine Teyssier \\ Jean Monnet University - Coactis
}

Corresponding author: Alexis.Catanzaro@univ-st-etienne.fr

\begin{abstract}
The purpose of the study is to analyze the effectiveness of public policies on the international performance of the small and medium- sized enterprises (SMEs). Specifically, we investigate the effect of public export promotion programs (EPPs) on two types of organizational capabilities, i.e. export capabilities which have been already used in previous modelization, and international risk management practices as an original variable intended to better explain the effectiveness of public policies on the SME's international performance. We use a quantitative methodology based on a structural equation modeling approach applied to a sample of 147 internationalized French SME that used EPPs. Our results add value to theoretical and empirical knowledge on the effectiveness of public support programs on the international performance of SMEs, since we demonstrate an indirect effect between EPPs and international performance, through export capabilities and risk management practices. We also show that by strengthening the risk management practices, EPPs stimulate the SME in implementing foreign direct investment strategies.
\end{abstract}

JEL classification: F23 - L25 - L38 - M16 - G32

Keywords: SMEs - Export promotion programs - International performance - Organizational capabilities - Risk management practices - Structural equation models - France

\section{Introduction}

In the today globalized environment, small and medium enterprises SMEs play a pivotal role in the development of a country, its employment growth, its innovation capacity, and its competitiveness on a global scale. It is now well accepted that, as their bigger counterparts, SMEs, whatever their age, can take part of the international opportunities, then strengthening their weight in the national economy and wealth (Belhoste et al., 2019). Internationalization can be seen as an entrepreneurial process (Schweizer et al., 2010) of discovery, enactment, evaluation, and exploitation of opportunities - across national borders - to create future goods and services (Oviatt and McDougall, 2005). It is also "the process of adapting a firm's operations (strategy, structure, resource, etc.) to international environments" (Calof and Beamish, 1995). Thereby, to exploit an international opportunity implies an internal adaptation to the international environment. However, this process of opportunity exploitation and internal adaptation is uncertain as the international environment is generally qualified as an unfamiliar and high-risk environment, especially for SMEs who know strong financial and non-financial resource constraints (Oviatt et al., 2004; Casson and Da Silva Lopes, 2013; Bannõ et al., 2014; Amankwah-Amoah and Wang, 2019). Indeed, many of them face the so-called "liability of smallness and foreignness" that puts them in a disadvantageous position to operate successfully on an international scale, i.e., by meeting growth and profitability (Majocchi and Zucchella, 2003; Lu and Beamish, 2006; De Maeseneire and Claeys, 2012). Further, many enterprises, especially small and medium-sized ones, do not make the most of the all of the potential of foreign markets or renounce engaging in international trade because of numerous cultural or psychic distance barriers to entry, identify and exploit opportunities in international environments (Acs et al., 1997; Oviatt and McDougall, 2005; Kraus et al., 2015; Dimitratos et al., 2016), and a lack of resources and capabilities to assume specific international risks (Shrader et al., 2000; Freixanet, 2012; Paul et al., 
2017; Malca et al., 2019). Therefore, SMEs crucially need to develop their resources and capabilities if they want to overcome these barriers and expand their international presence (Oviatt and McDougall, 2005).

In recent decades, most governments have developed numerous public support measures, like export promotion programs (EPPs), intended to help SMEs overcome various obstacles in their internationalization process and minimize the risks associated with international activities (Lloyd-Reason et al., 2009; Yannopoulos, 2010; Lederman et al., 2010; Francis and Collins-Dodd, 2004; Leonidou et al., 2011; Freixanet, 2012; Bannò et al., 2014; Cumming et al., 2015). EPPs were especially designed with small firms in mind (Ahmed et al., 2002) to help them to enhance their international entrepreneurial initiatives and expand internationally in a successful way (Leonidou et al., 2015). These public supports can be classified into three major types, i.e. informational, operational and financial supports (Catanzaro et al., 2015). They are considered by some authors to be "external resources" (Seringhaus, 1986), either tangible (financial) or intangible (information, knowledge, relationships, and organizational advice), intended to improve the firm's internal resources and capabilities (Francis and Collins-Dodd, 2004; Malca et al., 2019).

In the context of financial restrictions on public expenses, the effectiveness of these support programs has become a crucial issue (Leonidou et al., 2011; Bannò et al., 2014; Catanzaro et al., 2018; Belhoste et al., 2019). Consequently, the evaluation of these programs used by SMEs is a major challenge. Academic reviews still provide relevant information on internationalization support and its effectiveness (Freixanet, 2012; Bannò et al., 2014; Catanzaro et al., 2018; Malca et al., 2019). But the literature is not unanimous regarding the effectiveness of these programs on SME performance, and the empirical results are inconclusive or contradictory (Gençtürk and Kotabe, 2001; Francis and Collins-Dodd, 2004; Freixanet, 2012; Love and Roper, 2015; Broocks and Van Biesebroeck, 2017; Malca et al., 2019).

These conflicting results call for further researches, suggesting that the relationships between support programs and firm's performance should be treated indirectly, in the aim of investigating which internal resources and capabilities impacting the international performance of the firm can be improved by public supports, and deepening the understanding of how public supports affect international performance (Filipe-Lages and Montgomery, 2005). Indeed, although numerous studies have considered the effect of EPPs on the company's performance, most of them have assumed a direct effect on such performance. However, an increasing number of studies consider that the performance is more the result of the decisions made, and that the public programs used are conditionants of such decisions (Leonidou et al., 2011; Malca et al., 2019). The association between the use of EPPs and international performance is probably not direct but rather is achieved through an enhancement of the firm's organizational resources and capabilities required to operate internationally (Leonidou et al., 2011). For instance, a firm involvement in a public program can have an effect on the firm's behavior, due to the contacts and the interaction with the agency's specialists allowing learning about strategies, processes, administratives practices and eventually an adjustment of internal management processes (Bannõ et al., 2014), which in turn have a positive impact on performance. There is a need to consider the impact of EPPs on internal variables of the firm (resources and capabilities) and the effect of those latter on international performance, through an indirect effect (Wheeler et al., 2008; Freixanet, 2012; Malca et al., 2019).

On this aspect, the literature has demonstrated a positive and significant relationship between government programs and the development of internationalization-related resources and capabilities (Francis and Collins-Dodd, 2004; Fang et al. 2007; Leonidou et al., 2011; Bannõ et al., 2014; Cumming et al., 2015; Spyropoulou et al., 2018, Ojala, 2009; Catanzaro et al., 2018). These programs are actually designed to provide SMEs the required resources that they lack (Wilkinson and Brouthers, 2006), allowing them to develop operational capabilities for their international strategy and development. Therefore, EPPs are designed to reinforce the SMEs' organizational resources and capacities in order to attain a higher level of international performance. In their comprehensive study, Leonidou et al. (2011) studied the link between EPPs and organisational capabilities, more specifically the business identification capabilities, the relationship-building capabilities, and the innovation capabilities, whereas the numerous others studies were focused on resources as assets (foreign markets knowledge, relational capital, etc).

However, the specific impact of EPPs on risk management practices, considered as a particular type of organizational capabilities, has not been explicitly and empirically explored in the literature, while EPPs also addressed the question of international risks (Bannõ et al., 2014). This ascertainment is relatively surprising, given on the one hand the abundant literature that has developed over the past twenty years in the field of risk management (Henschel, 2006, 2010; Gao et al., 2011; Paape and Speklé, 2012; Verbano and Venturini 2013; Falkner and Hiebl, 2015; Rostami et al., 2015), and on the other hand the critical need to manage risks in the internationalization process (Miller, 1992; Oviatt and McDougall, 1997; Shrader et al., 2000; Ahmed et al., 2002). To go further on these issues, the purpose of this study is to explain the international performance of SMEs through the analysis of an empirical model concerning the external and internal factors of the firm (Wheeler et al., 2008, Malca et al., 2019). More precisely, our model is intended to investigate the effect of EPPs on two types of organizational capabilities in the firms, i.e. the export capabilities and the international risk management practices, considered as two explanatory levers of the SME's international performance. The central assumption of our conceptual model is that the more significant the use of EPPs is, the more developed the export capabilities and the international risk management practices will be, and then the better the international performance of the firm will be. 
For this purpose, we adopt the resource-based view (Wernerfelt, 1984, 2011; Barney, 1991; Barney et al., 2011), which addresses the central issue of the specific role of resources and capabilities on the performance. It is a rich theoretical framework for testing models of international performance (Peng, 2001; Westhead et al., 2001; Dhanaraj and Beamish, 2003; Wilkinson and Brouthers, 2006; Bannõ et al., 2014; Leonidou et al., 2011; Malca et al., 2019). In our study, EPPs are considered as "external resources" (Seringhaus, 1986), whereas export capabilities and international risk management practices are considered as internal strategic resources. The latters are likely to increase the company's capacity to identify, assess and exploit the international opportunities available to it, while managing the associated risks with more developed internal practices in order to limit the negative impacts of various risks on the achievement of its objectives. On a methodological view, we use a quantitative method based on a structural equation modeling approach applied to a sample of 147 internationalized French SMEs.

Our results add value to theoretical and empirical knowledge on the effectiveness of public support programs on the international performance of SMEs. We demonstrate an indirect effect between EPPs and international performance, by integrating the already used "export capabilities" variable (Leonidou et al., 2011) but also by adding the "international risk management practices" variable that, to our knowledge, has never been empirically integrated in the previous studies. Thus, we show that EPPs positively and significantly improve several types of internal capabilities in the SMEs which, in turn, positively influence its international performance. However, while export capabilities positively and significantly impact export turnover, risk management practices positively and significantly improve foreign direct investments. By strengthening the extent of risk management practices through the firm, EPPs stimulate the SME in implementing various international development modes. By highlighting these effects, we expect to enhance the theoretical and empirical knowledge on the levers of the internationalization success of small firms and the combined role of public policies and organizational capabilities on their performance.

In the following, we, first, highlight the need to focus on EPPs, the organizational capabilities of SMEs, and their joint impact on international performance. We also present the theoretical framework of the model and the research hypotheses. Second, we describe the methodology of the research, and, in the next section, the results obtained. Finally, we discuss the implications for researchers and the recommendations for policy-makers and managers. We finish with some limitations and provide further research directions.

\section{Conceptual framework and hypothesis}

\subsection{The link between EPPs and export resources and capabilities}

In this study, we distinguish three types of supports services provided by EPPs, i.e. informational, operational and financial support (Leonidou et al., 2011; Catanzaro et al., 2015; Malca et al., 2019). Informational support, provided by the majority of public structures, includes seminars, meetings, conferences or training sessions providing market information about foreign market opportunities, specific foreign markets and their related risks, export practices, detailed documentation and market studies, knowledge about specific needs of customers abroad, and foreign language support. This first category of support joins the two constructs developed by Leonidou et al. (2011), i.e. the information-related EPPs and the education and training-related EPPs. Operational support (Catanzaro et al., 2015), which can be compared to the trade mobility-related EPPs used by Leonidou et al. (2011), is related to services involving contact with the foreign markets and their actors, such as trade shows abroad, marketing or regulatory assistance, foreign buyers' visits, prospecting missions or networking services with other support structures or local partners abroad. These operational supports include both logistic aids and high-value contacts, and can also bring useful information to the firm about foreign markets, customers' needs, local networks, legal or social rules, and their related risks. Finally, financial support provided by insurance or financial public institutions (such as Bpifrance in the French context) concerns loans or subsidies designated to finance prospection or market study expenses, guarantees and insurance for covering project failure, non-payment of customers or exchange rate risk (Bannõ et al., 2014). Thanks to these financial aids, SMEs can have access to capital at a lower cost, frequently without collateral guarantees required and enabling the financing of more ambitious and riskier international projects, such as foreign direct investment (De Maeseneire and Claeys, 2012).

An increasing number of quantitative studies on the effectiveness of EPPs reveals that these programs, as an external helpful hand extended to the firm (Seringhaus, 1986), are instrumental in enhancing organizational resources and capabilities (Leonidou et al., 2011). Organizational resources can be considered as the firm's specific assets available to the foreign business activities, whereas organizational capabilities can be viewed as the processes by which the firm develops, combines and transforms these resources into outputs or value offerings (Wernerfelt, 1984; Kaleka, 2002). In other words, capabilities can be defined as the ability to accomplish something, to perform an activity, using a set of tangible and intangible organizational resources (Helfat and Peteraf, 2003). In the SME context, it is a major issue to know if EPPs provide to the firm some of these organizational resources and capabilities that they lack to succeed in their internationalization strategy (Lloyd-Reason et al., 2009; Leonidou et al., 2011; Bannõ et al., 2014; Malca et al., 2019). 
Historically, the link between EPPs and organizational resources, i.e assets, was first explored. In these studies, EPPs are considered as instruments in enhancing organizational resources in the firm, both tangible and intangible. Financial-support component of EPPs, especially the loans or the subsidies, undoubtedly bring tangible resources, since the access to capital remains a critical aspect in the small firm's international strategy (Wright et al., 2007). Given the relatively high working capital and financial liquidity requirements of export operations, access to financial resources is essential in enabling export ventures to effectively engage in relationship building and marketing activities in export markets (Morgan et al., 2006). But beyond their direct financial assistance, they can be converted into other types of resources (Bannõ et al., 2014), for example, the acquisition of tangible or intangible resources that promote internationalization, such as external consulting or training. Moreover, it may have an indirect effect, as it may convey positive information about the quality of the firm both to its equity holders and the other potential investors, thereby facilitating access to private financing (Becchetti and Trovato, 2002). As some previous authors showed (Francis and Collins-Dodd, 2004), other types of EPPs are more intellectual, managerial or relational, and bring to the firm more intangible resources. So, among the intangible resources that are made available to the firm through the EPPs, specific and suitable information is a crucial organizational resource, because it could helps the firm, in a targeted and precise way, reduce the high level of uncertainty that characterizes the heterogeneous, sophisticated, and turbulent international business environment (Leonidou et al., 2011). Most SMEs do not have the means to acquire foreign market information, are not aware of the specific sources from which this information can be extracted, do not know the specific type of information required to identify and/or analyse foreign markets, or face difficulties in effectively utilizing the information collected. Informational supports could strengthen the specific knowledge that the SME has about foreign market demand, foreign business practices, export regulations or logistical requirements (Leonidou et al., 2011). Moreover, internal managerial resources could be strengthened by EPP, for instance special managerial interest or commitment in exporting, specialized managerial skills or competencies in exporting (Kaleka, 2002; Morgan et al., 2006; Leonidou et al., 2011).

Thereby, in a second objective, and in addition to strengthening the firm's organizational resources, EPPs have been considered as instrumental in enhancing SME's organizational capabilities. It is a pertinent path in terms of analyzing the impact of EPPs on international performance, since it allows explicitly deepening the understanding of the mechanism by which the company articulates or orchestrates (Sirmon et al., 2011) the resources provided by the EPPs in a value creation process. Authors generally defined different types of export capabilities that are likely to be reinforced through the EPPs, for instance the business identification capabilities, the relationship-building capabilities or the innovation capabilities (Kaleka, 2002; Morgan et al., 2006; Leonidou et al., 2011). For example, the business identification capabilities refer to the capacity of the firm to adopt a systematic approach to locate, analyze and exploit foreign opportunities, contacting prospective foreign customers or acquiring specialized information in foreign markets. The relationship-building capabilities concern the building and maintaining of close relationships with foreign intermediaries and customers, understanding their requirements, by having the ability to overcome obstacles related to the communication problems resulting from the geographic, cultural or linguistic distance. Finally, the innovation capabilities refer to product-market development emphasis on introducing new products, new methods and ideas in the production process, to meet specific foreign customer needs and adopting innovative marketing techniques and tools. These export capabilities refer to operational capabilities, that can be defined as "high-level routines (or collection of routines) that, together with its implementing input flows, confers upon an organization's management a set of decision options for producing significant outputs of a particular type" (Winter, 2000, p.983). In our context, operational capability therefore involves carrying out an international activity, such as entering a new foreign market, using a set of routines and resources to execute and coordinate the variety of tasks required to complete the activity (Helfat and Peteraf, 2003).

Rare studies have considered and demonstrated the impact of EPPs on the organizational capabilities of the firm (Leonidou et al., 2011), compared to the EPPs-resources relationship which attracted most studies (Malca et al, 2019). Then, we focus on the EPPs influence on the export capabilities of the internationalized SME. From the previous analysis, and in line with previous findings, the first hypothesis constituting our hypothesized research model (Fig. 1) is proposed:

\section{H1. EPPS have a positive effect on the SMEs' export capabilities}

However, regarding the critical need to manage risks in the internationalization process (Miller, 1992; Oviatt and McDougall, 1997; Shrader et al., 2000; Ahmed et al., 2002) and the potential effect of EPPs on it (Bannõ et al., 2014), we also take into account another organizational capability somewhat forgotten from previous work on EPPs influence, i.e. the international risk management practices.

\subsection{The link between EPPs and risk management practices}

As previously mentioned, recent literature (Wheeler et al., 2008; Leonidou et al., 2011; Freixanet, 2012; Malca et al., 2019) invites further studies to examine how internal organizational capabilities are developed to foster 
international performance in SMEs receiving EPPs supports. In this sense, although risk appears to be widely present in international business field, the potential impact of EPPs on risk management practices, as a particular type of organizational capabilities intended to reduce the negative impacts of risks on the international development and performance, has not been empirically explored in the literature. It is relatively unexpected, since the majority of studies on the SME's internationalization insists on the critical need to manage international risks in the very constrained context of small firms (Miller, 1992; Oviatt and McDougall, 1997; Shrader et al., 2000; Ahmed et al., 2002). We argue EPPs are likely to play a role in enhancing risk management practices.

The abundant literature that has developed over the past 20 years in the field of risk management (Henschel, 2006, 2010; Gao et al., 2011; Paape and Speklé, 2012; Verbano and Venturini 2013; Falkner and Hiebl, 2015; Rostami et al., 2015) can help us to better understand the challenges of risk management capability in the internationalized $\mathrm{SME}^{1}$. Actually, organizations struggle with the design of their risk management systems, seeking for effective approaches that suit their needs (Paape and Speklé, 2012). This arguments are especially true for the SMEs, whose organizational resources are severely constrained. Indeed, literature on risk management in the small business context clearly shows that the risk management system is unfortunately less developed in SME, because of the lack of resources, leading to weakness in management skills and knowledge of tools and techniques for managing risks (Henschel, 2006; Jayathilake, 2012; Aureli and Salvatori, 2013). If we compare SMEs' risk management practices to those of larger companies, we can assess that risk management in small firms is still pragmatically implemented and reactively established following peaks of increased risk (such as external acquisitions, international openings, initial public offerings or innovation stages), often in an implicit or even intuitive way (Bérard and Teyssier, 2017). SMEs generally do not present a risk manager identified as such nor a function or service dedicated to risk management, while owner-managers are responsible for overseeing all risk management activities within the firm (Henschel, 2006; Jayathilake, 2012; Aureli and Salvatori, 2013). Financially speaking, the percentage of turnover that the SME can afford to devote to risk management is rather low, and this budget is generally intended for external consultants, particularly to manage specific types of risks, such as legal risks, environmental risks or financial risks, or to obtain certifications (Aureli and Salvatori, 2013). Consequently, SMEs are struggling to build a valuable risk management capability (Gao et al., 2011) which yet could strengthen their ability to effectively respond to environmental opportunities and threats. Risk management capability-building initiatives are less likely to be found in SMEs, partly because they do not have the necessary expertise and know-how. Moreover, risk management practices in SMEs may be so informal that they could in turn, inhibit their being shared and thus also thier building risk management capacity (Gao et al., 2011). This lack of subsequent capability to develop risk management practices is likely to restrict the sustainable development of such firms. In an international context in which business risks are amplified, SMEs could really suffer more than their larger counterparts from this lack of capabilities. It is the reason why both local and national governments are increasingly concerned with the lack of risk management capabilities amongst SMEs, and in many instances are attempting to make provision for risk management training and capability building (Gao et al., 2011).

In this study, we assume that because SMEs often lack adequate capabilities in their risk management, relationships between the firm and the public structures that support them in their internationalization process are likely to bring specific risk management capabilities that the firm cannot build by itself. These supports, especially because they bring specific informations, knowledges and advices, raise awareness of the firm about risk exposures and risk management challenges. Thus, it may be expected that, in a first time, individual employees could play a substantial role in establishing and enacting risk management procedures, in a "bottom-up" way. But if the purpose is to provide a reasonable measure of guarantee regarding the effectiveness of the risk management strategies, and to ensure that a greater value can be created through the firm's ability to manage unexpected outcomes induced by risks, it may be expected that the firm implements more established or structured practices, driven by the organization, and leading to the development of a "top-down" risk management culture (Silva et al., 2013). Thus, internal control mechanisms, formal procedures and reporting practices intended to address, report and monitor international risks become crucial, in order to support the risk management strategy that the firm has adopted. Internal formalized practices that are implemented are of critical importance to the success of risk management, in that they play a critical

\footnotetext{
${ }^{1}$ We can not ignore the interest in the Enterprise Risk Management -ERM- concept, that has grown rapidly over the past two decades, with regulators, professional associations calling for its adoption, the most common being the COSO framework (COSO, 2004). This approach of risk management, largely based on the reference to large companies, suggests that firms address all their risks (operational, financial, legal, strategic) comprehensively and coherently, instead of managing them individually (Bromiley et al., 2015). The aim of this holistic framework is the identification, assessment and monitoring of all threats and opportunities facing a firm, in order to promote increased risk-management awareness and culture, translating into mature operational and strategic management decisions and, hence, offers competitive advantage (Farrell and Gallagher, 2005; Nocco and Stulz, 2006; Brustbauer, 2014). However, it appears that the best practices that these frameworks are supposed to provide do not have a clear theoretical or empirical foundation, and their effectiveness is still largely unanswered (Paape and Speklé, 2012). The application of a standardized framework does not systematically help to improve risk management quality, but, on the contrary, less structured, less standardized, more subjective and exploratory risk management approach to risk management would be more relevant (Mikes, 2009; Paape and Speklé, 2012). Moreover, ERM is frequently an "umbrella concept" and finally refers to a very heterogeneous set of more or less informal practices (Power, 2009). These arguments invite us not to use an over-sized analytical framework of risk management in our research, fundamentally anchored in the small business context for which the pragmatic nature of risk management is essential.
} 
role in the management of knowledge flow within SMEs (Silva et al., 2013) and especially in more turbulent environments, such as international environments, because they facilitate sense making and provides a stable frame of reference to understand rapid changes (Davila et al., 2009; Subramaniam et al., 2011). From our point of view, when SMEs use the services provided by public structures through EPPs, there is a greater propensity for them to implement internal controls and procedures, ensuring that the resources acquired are used wisely and guaranteeing the effectiveness of the international risk management practices. These suggestions might raise the question of whether SMEs can actually use EPPs at least partially as substitutes for risk management practices, making less relevant the empirical relationship between the two concepts. However, risk management practices as we consider in this study refer to internal controls, formal procedures and reporting tools to manage international risks and encourage the exchange of information within the company. In that sense, EPPs cannot substitute such internal activities, as public player's role is not to be an external component of the firm, neither a maker nor a controller. It is a source of intellectual or experiential resources and specialized knowledge about export markets and the risks associated. In this sense, EPPs act as facilitators which push or raise awareness of the firm about risks exposures and management, give the firm the correct information about potential risks in the targeted markets, and how to manage it. It is up to the company to ensure that these relevant and suitable resources are used as efficiently as possible. We therefore propose the following hypothesis:

\section{H2. EPPs have a positive effect on the SMEs international risk management practices}

\subsection{The link between export capabilities and international performance}

Our model is rooted in the RBV of the firm (Wernerfelt, 1984, 2011; Barney, 1991; Barney et al., 2011), which stresses that the firm's resources and capabilities are crucial to understanding business performance. According to this theory, the conception and implementation of a specific strategy require various resources and capabilities that are vital in achieving a sustained competitive advantage. The VRIO framework (valuable, rare, inimitable resources, appropriate organizational support to generate a sustainable competitive advantage) (Barney, 2007) stipulates that these resources must be valuable for exploiting opportunities and/or neutralizing threats from the environment, rare among the firm's current and potential competitors, imperfectly imitable by competitors and finally must be an appropriate organizational support difficult to replace with equivalent substitutes that would allow achievement of the same positional advantages. These characteristics are the basis for designing and implementing strategies that subsequently help the firm to achieve sustainable competitive advantages and improve effectiveness and efficiency (Barney, 1991; Bharadwaj et al., 1993).

As already demonstrated in previous studies, EPPs contribute to reinforcing the SME's organizational capabilities, i.e. export capabilities, and this effect should be reflected in a positive influence on the firm's international performance. Indeed, in order to design and implement effective international strategy, SMEs must have both an adequate accumulation of key resources and the right combination of these resources to use effectively in various strategic actions in foreign markets (Morgan et al., 2006). In an internationalization context, certain key capabilities provided by EPPs are particularly vital in developing effective export marketing strategies. These include the export capabilities previously developed (Leonidou et al., 2011) related to identification, evaluation, and exploitation of opportunities that arise in foreign markets, based on the possession of special marketing knowledge and exclusive information relevant to international markets and the building of sound relationships with distributors, customers and other parties to better understand and respond their requirements. Then, rather than studying a direct effect between EPPs and the firm's international performance, which provided contradictory (Lages and Montgomery, 2005) or inconclusive results (Francis and Collins-Dodd 2004; Wilkinson and Brouthers, 2006; Catanzaro et al., 2018), we assess in this study its indirect effect. EPPs would play a role through the enhancement of resources and capabilities that benefit the firm, and the latters will positively influence their performance (Bannõ et al., 2014). This indirect effect has been widely demonstrated in international business, and especially in the studies whose objective is to articulate the public support programs and the performance of the SMEs internationalization strategy (Leonidou et al., 2011; Bannõ et al., 2014). This is, for instance, what Catanzaro et al. (2018) and Malca et al. (2019) recently demonstrated with, respectively, the relational capital and the export capabilities of the firm. Consequently, we are interested in the effect of the capabilities, influenced by the EPPs, on the international performance of the firm, reflecting a path of "EPPs-capabilities-performance". Following Leonidou et al. (2011) and Malca et al. (2019), we therefore propose the following hypothesis:

\section{H3. Export capabilities have a positive effect on the SME's international performance}

\subsection{The link between risk management practices and international performance}


The international environment remains fundamentally riskier for an SME than the familiar national one. We can therefore assume that the SME that would be able to secure its international strategy would then be able to possess a specific resource supposed to bring even greater value. For example, the capacity to better identify a risk of corruption or customer failure in a foreign country is an advantage. But if the firm also has the capability of regularly reviewing internal controls to manage this specific risk, widely sharing information and knowledge about it through the firm, addressing and reporting on a ongoing basis the changes in the nature of this risk, then this firm possesses a specific advantage for international success. Risk management practices is a valuable capacity, supporting the development of the business strategy by reducing potential risks and exploiting opportunities effectively. The other firms, those who do not have this capacity, will either stay out the foreign market if the anticipated risks are too high or withdraw if the risks finally occurred are too impactful (Casson and Da Silva Lopes, 2013).

Literature on the effect of risk management capability on firm performance is relatively abundant. Empirical results are mixed because of the measure of variables (nature of risk management practices, degree of maturity of these practices, firm performance), the impact of contingency factors (Gordon et al., 2009) or a potential non-linear effect such as that described by Busse et al. (2015) or Haans et al. (2016) ${ }^{2}$. According to the literature on the relationship between risk management and performance, we can conclude that in the SME context, the implementation of more risk management practices would have a positive impact on the firm performance. In terms of development strategy, some authors have shown that companies adopting "active" risk management practices are more likely to have aggressive strategic orientations, aimed at gaining competitive advantages, especially those investing in product development and expansion into new markets (Hoyt and Liebenberg, 2011; Brustbauer, 2014; Falkner and Hiebl, 2015). More developed risk management practices could allow clarifying the types of risks that have been identified as critical and illuminate the ways to mitigate them (Subramaniam et al., 2011). By allowing monitoring and managing risks, these practices strengthen managers' awareness of the level of risk they are likely to incur, which facilitates better operational and strategic decision making by the organization (Hoyt and Liebenberg, 2011). Consequently, these practices are likely to restrict the negative impacts of the various risks on the achievement of the firm's objectives, avoiding the worsening of production capacity and market share, as well as the occurrence of financial losses or insolvency problems (Verbano and Venturini, 2013; Rostami et al., 2015). This positive economic impact could be explained by others organizational outcomes. For instance, risk management practices may reinforce cost optimization and efficiency (Aureli and Salvatori, 2013) or lead to positive attitudes among employees by increasing the clarity and understanding of job roles within the organization, reducing working conflicts and improving task coordination (Subramaniam et al., 2011).

Consequently, risk management practices, far from being ordinary resources, are considered in this study as strategic resources, rooted in the resource-based view (Barney, 1991, 2007). They are valuable, rare and expensive to imitate by others SMEs, given the constraints that SMEs face in building an adequate and effective risk management capacity. Finally, added to the bundle of resources, whether internal or provided by external actors such as EPPs, they are integrated in a resource orchestration process (Sirmon et al., 2011), implemented by managers to effectively structure, bundle, and leverage firm resources. With export capabilities, risk management practices become a crucial and appropriate organizational support intended to generate a sustainable competitive advantage, because they are likely to secure the implementation of the international development strategy. This competitive advantage fits in both the ability of the company to export more, but also to secure more direct presence abroad. The following hypotheses arising from the previous developments allow us to finalize our research model (Fig. 1) in the resource-based framework, with the aim of empirically testing the indirect effect of public supports on the firm performance:

\section{H4. Risk management practices have a positive effect on the SME's international performance}

Figure 1 presents our hypothesized research model.

\section{Figure 1}

\footnotetext{
${ }^{2}$ Researches in strategic management has recently developed and tested models that not suggest a simple linear relationship between an antecedent variable (e.g. practices or formal procedures) and a desirable outcome variable (e.g. performance, innovation, effectiveness), but a U-shaped (or inverted U-shaped) relationship (Busse et al., 2015; Haans et al., 2016). Many relationships studied follow an inverted U-shaped pattern, meaning that "too much can be as bad as too little". One explanation of this phenomenon can be found in the "too-much-of-a-goodthing" effect (Busse et al., 2015), which provides from a compensation of desired effects (benefits) by parallel and undesired effects (costs). For example, in the entrepreneurship field, Chrisman et al. (2005) tested an inverted U-shaped relationship between the amount of formal planning and firm performance, because beyond a certain level of formalization, the incremental benefits (understanding of capacities and resources, development of long-term policies) are not sufficient to support the incremental costs (overconfidence and cognitive rigidity). However, in our study, we do not sense this quadratic effect, because of the context of the businesses and the research topic in itself. The companies concerned by public support are small companies, poorly equipped in terms of risk management tools, who can only benefit from being helped in the development of managerial practices. There is little risk that the costs of implementing risk management practices exceed the benefits generated. This is all the more true that public aid provided by specialists is very targeted and adapted to the firm's characteristics (specially its size) and to the firm's specific international strategy, and that leaders prefer to set up practices sized to their needs. A risk of overconfidence or organizational rigidity is less conceivable in the small business context.
} 


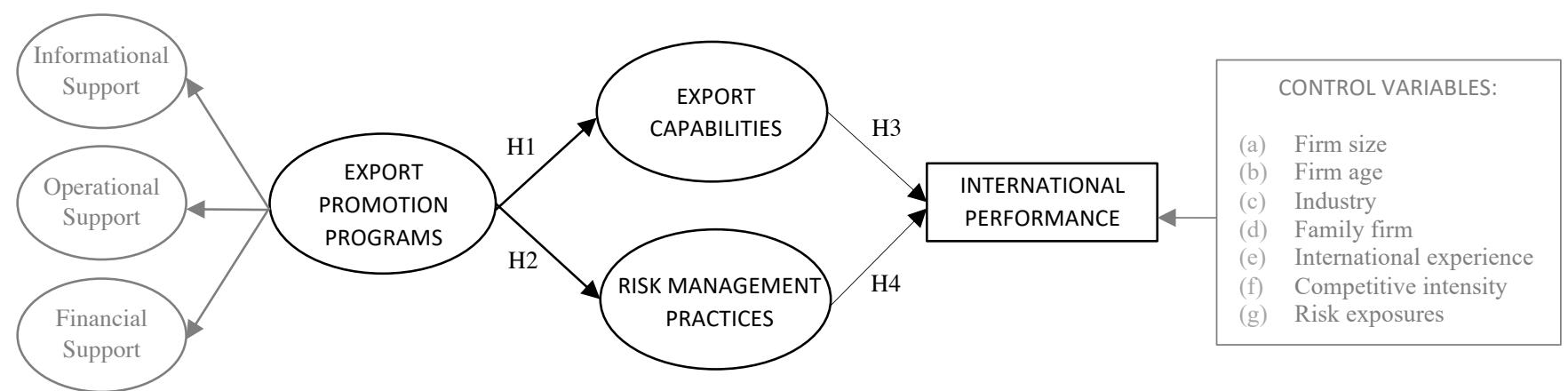

\section{Research methodology}

After explaining the institutional setting of EPPs in the French territory, we specifically present the research methodology, i.e., the method for data collection and the sample, then the description of measurement variables and their statistical reliability and validity.

\subsection{Institutional setting of EPPs in France}

The data are collected on the French territory. On this area specifically, public support structures have multiplied, as have the number of dedicated international programs encouraged by public policymakers, who view SMEs' international development as a new engine of economic development. Several reforms have been initiated to rationalize public aid, but despite this, the great diversity of stakeholders is one of the most surprising features of the French support system and sometimes leads to under-optimal situations. Among these reforms, the creation on January 1, 2015, of Business France, which gathers three types of activities, i.e. "export" (support for export), "investment" (attraction of foreign investment) and "promotion" (promotion of the economic image of France abroad) within the same agency, represented a major step in the redefinition of public policy in favor of international performance. In line with Business France, several major players characterize the landscape of public aid abroad, such as insurance or financial institutions (the French Public Bank of Investment, the French Insurance Company for Foreign Trade), institutional and business organizations or networks (the International Chamber of Commerce and Industry, the Foreign Trade Advisers of France -chosen by decree of the Prime Minister on the proposal of the Minister of Foreign Trade for their expertise and experience abroad-, the Organization of Specialized Operators of International Trade, the General Confederation of Small and Medium Enterprises, and the Regional Directions of Foreign Trade placed under the authority of the Regional Prefect). In these public structures, private consultants are generally acknowledged for their specialized experience and expertise about the international environment. In parallel, private structures exist, but they are much less numerous and the resources and supports they allocate generally come from public subsidies or programs, for instance, within a public delegation.

In France, EPPs are available to any firm subject to demonstrating an international development potential. Indeed, because public players work together, they decided to give to the Chamber of Commerce and Industry's (CCI) international departement a role of determining the company's strengths and weaknesses and potential to start or reinforce its internationalization development. That's why a diagnosis of the company and its export capacity is the first step into the EPPs device. When the potential is demonstrated, the CCI advisor will connect the firm with the others players according to its needs of resources and capabilities. In that sense, companies receiving EPPs share some characteristics in terms of minimum international potential. And all kinds of companies in terms of age, size or industry, can be supported, although most companies supported in the French context are SMEs (Bentejac and Desponts, 2013) because EPPs were designed with small firms in mind (Ahmed et al., 2002). 


\subsection{Data collection and sample}

In this study, we only targeted SMEs supported by public players to go internationally. We had two possibilities about sampling: find or buy a database already existing, or work with export support organizations to get an access to companies. To avoid selection bias, we decided not to work with export support organizations, considering the risk that these organizations give to us an access to convenience sample of only successful supported SMEs. Thus, we prefered to ask to a private marketing company an access to a random sample based on three criteria: companies of the SME type, French companies, and internationalized one. CEOs of internationalized SMEs were approached by email and invited to participate in the survey. Only CEOs has been contacted, as the database we got from the private marketing company only provided the CEOs' contact. To assure rich information from the respondents, our study follows a two-step research design: interviews and a research survey. First, we conducted face-to-face interviews and discussions with six people with different profiles: two academics, two consultants, and two managers of internationalized SMEs. These respondents were encouraged to provide comments or to rewrite items in the questionnaire they felt were ambiguous or problematic. The feedback collected from the pilot test was used to modify the first version of the questionnaire. The final copy of the questionnaire was sent to our random sample of SMEs through an online questionnaire. The questionnaire was preceded by an introductory letter that briefly described the aims of the research and explained how the study itself would benefit respondents and their companies. A total of 167 questionnaires were collected, and after excluding those with missing data $(n=8)$, unclear or contradictory answers $(n=4)$, or those not corresponding to the targeted profile, 147 questionnaires were used for the data analysis. The main characteristics of the survey sample are presented in Table 1. Based on the European Commission's (2005) definition of SMEs, we use various criteria to identify our target population. First, the companies should be independent (not more than $25 \%$ of its shares controlled by another firm). Second, the staff headcount should not exceed 250 employees. Finally, the annual turnover should be less than 50 million euros. The firms of our sample shared several features. The mean age was 37 years, and 62 of them (45.6 percent) had fewer than 10 employees. The ratio of firm size categories in our sample (45.6\% of micro firms) is quite representative of the equilibrium we have in terms of supported SMEs' size in the French context. Indeed, experts we previously interviewed told us that approximately half of the supported firms are micro-firms with less than 10 employees. Almost 60 percent of firms derived more than 20 percent of their turnover from exports, 73.5 percent of the firms were present in at least 4 countries, and 62 firms ( 42.2 percent) were present in at least 10 countries. Finally, more than $60 \%$ of SMEs are manufacturing companies.

Table 1

Description of study sample

\begin{tabular}{lrr}
\hline Mean Age & \multicolumn{2}{c}{37} \\
Size & Number & Percent \\
Fewer than 10 employees & 62 & 45.6 \\
Between 10 and 49 employees & 59 & 40.1 \\
Between 50 and 250 employees & 26 & 14.3 \\
Industry & & \\
Computer and scientific services industry & 25 & 17 \\
Other services industry & 15 & 10.2 \\
Agro-industry & 17 & 11.6 \\
Manufacturing industry & 90 & 61.2 \\
Export Intensity & & \\
Less than 20\% & 60 & 40.8 \\
21-50\% & 39 & 26.5 \\
More than 50\% & 48 & 32.7 \\
Number of Foreign Markets & & \\
1-3 countries & 39 & 26.5 \\
4-6 countries & 30 & 20.4 \\
7-9 countries & 16 & 10.9 \\
10 or more countries & 62 & 42.2 \\
Global Turnover & & \\
Less than 1 million euros & 101 & 68.7 \\
1 million-5 million euros & 39 & 26.5 \\
5 million-50 million euros & 7 & 4.8 \\
\hline
\end{tabular}

3.3. Measurement variables 
The content of all measurement variables is detailed in Appendix A. Export promotion programs are a secondorder factor built on the three categories of support types, i.e., informational, operational and financial support, distinguished in the literature (Lederman et al., 2011; Catanzaro et al., 2015). We used a five-point Likert-type scale to assess the firm's frequency of utilization of the different support programs over the previous five years (Wilkinson and Brouthers, 2006), considering the necessary lapse between the use of the support and its concrete materialization through organizational or economic outcomes. Informational support refers to the frequency of use of advice for international development (strategy, marketing, entry mode selection, and the choice of countries) (Support1) and participation in practical or technical training in international business (Support2) provided by public agencies. Operational support concerns help in attending international fairs (Support 3) and prospecting foreign markets (Support 4). Finally, financial support refers to guarantees to limit economic risk (Support 5) and loans for expenses related to international exploration (Support 6). As previous studies about EPPs effectiveness using structural equation modeling method, we built the EPPs variable as fully reflective construct. Nevertheless, as a robustness check, we tested the structural model with EPPs as first-order reflective second-order formative construct. We got the exact same results than with the reflective construct, proving that this is not an issue for our results and contributions.

To measure the export capabilities of the firm, we used the Leonidou et al. (2011) scale. We focused on three items measured with a 5 points likert scale degree of accordance regarding (a) the capability to locating and analyzing potential foreign markets, (b) the capability to identifying attractive foreign business opportunities, and (c) the capability to contacting prospective foreign customers. Notice that the original scale measurement of Leonidou et al. (2011) is a second order factor with 8 items on 3 dimensions. In our study, after an exploratory and confirmatory factor analysis, we decided to retain only 3 items because the scale measurements with all the items impacted the fit adjustment of our structural model (Leonidou et al. met the same fit adjustment issue but decided to cut the model in two parts). However, if the main contribution of this study is focused on the risk management practices, we decided to conduct a robustness test by testing the final structural model with the original scale and all the items (despite its barely acceptable adjustment). We got the exact same results on all the hypothesis, proving that our "export capability" variable capture the exact same information than the one with all the items.

To assess the firm's risk management practices, we used some items from the risk management formalization scale measurement provided by Subramaniam et al. (2011). We focused on the items related to risk management practices, adapted to the international context and using a five-point scale. International risk management practices is then measured using three items in which respondents were asked about the extent to which they agreed with whether the organization (a) reviews internal controls to manage international risks, (b) has formal procedures for reporting international risks and (c) addresses and reports changes to international risks on a ongoing basis.

Different measures of performance outcomes could be reviewed (Katsikeas et al., 2000; Dhanaraj and Beamish, 2003; Wilkinson and Brouthers, 2006). Objective economic measures are based on foreign turnover, the rate of foreign turnover growth, profits or market shares. Non-economic or strategic measures are related to the degree of the international presence, such as the diversity of countries or geographic areas in which the firm is present (their number, for instance), and to the variety of international modes of implementation (exports, alliances or foreign direct investments). In this study, we retained the export turnover as an economic measure of international performance, and foreign direct investments as a non-economic and strategic measure. The export involvement, here export turnover, is the critical factor when designing appropriate EPPs (Freixanet, 2012). Exporting remains the method of internationalization most commonly adopted by SMEs, even for the most entrepreneurial ones (Kuivalainen et al., 2012; Cabrol and Nlemvo, 2012), because of the relative lower perceived risks induced by this type of strategy, characterized by limited costs, greater flexibility and low funds engagement, compared to other types of implantations, such as foreign direct investment (Bannõ et al., 2014). Nevertheless, in recent decades, an increasing number of SMEs have switched to other types of implantation (through the creation of permanent facilities abroad, such as branch offices or sales subsidiaries, or production subsidiaries) in both emerging and mature economies to internalize transaction-related risks, protect their assets, get close to their customers, and finally gain competitive advantages (Dominguez, 2018). But foreign direct investment entails a greater foreign resource commitment than exporting (Ahmed et al., 2002; Freixanet, 2012), is more difficult to reverse, less flexible in dealing with investment risks such as adverse market conditions (Bannõ et al., 2014) and it is harder to finance (De Maeseneire and Claeys, 2012). SMEs with strong export capabilities are better positioned to use foreign direct investment as entry modes in foreign markets. Considering the resource limitation of SMEs, establishing a subsidiary abroad can be also viewed as a success for this type of firm. Overall, foreign direct investments improve the long-term performance of the firm (Doukas and Lang, 2003) and move in the direction of SMEs' competitiveness and growth. They also allow diversification of international risks, making international development more sustainable in the market, for instance, in case of new legal constraints for exports in the market. Thus, we consider in this study foreign direct investment as a strategic measure of the international performance of the SME, complementary to the more economic measures.

Seven control variables are also integrated into the research model: (a) the firm's size, (b) the firm's age, (c) the industry, (d) the family nature or not of the business, (e) the international experience, i.e., the number of years of international business operations, (f) the competitive intensity, (g) and the risk exposures. The firm's size and age, and the international experience are intended to capture the extent of the firm's resources and its experience on 
international scene (Francis and Collins-Dodd, 2004; Johanson and Vahlne, 2009; Eriksson et al., 2014), through different levers such as internationalization experience gained from foreign country markets, market experience gained from doing business within a particular country, relationship experience gained from doing business in an individual business relationship, and network experience gained through interaction within the network. This experience could influence the relationship between EPPs, organizational capabilities and international performance. For example, firms differ greatly in terms of their assistance needs and their effectiveness, depending on their international experience, size, internal resources and capabilities, and export strategies (Faroque and Takahashi, 2012). The firm's international experience will contribute positively to its ability to recognize international growth opportunities (Hilmersson, 2014), and it is reasonable to assume that such experience will also contribute positively to the firm's ability to recognize and interpret warning signals in the international business environment. For taking into account the industry effect, we first used a dummy variable with manufacturing firms $(\mathrm{n}=107)$ as reference group (versus 'service firms' $; n=40)$, in line with Catanzaro et al. (2018) study about EPPs effectiveness. Second, to deepen our analysis of the industry effect, we tested the structural model by replacing the dummy variable, once with 'computer and scientific services industry' $(n=25)$ as reference group, once with 'other services industry' $(n=15)$, once with 'agro-industry' $(\mathrm{n}=17)$, and once with 'manufacturing industry' $(\mathrm{n}=90)$. Family firms is a dummy variable distinguishing between non family firm $(n=38)$ and family firm $(n=109)$. The competitive intensity is measured according to Birru et al. (2018) scale, based on Lisboa et al. (2011) and Zhou (2007), with 5 items on a 5 points likert scale degree of accordance. The items are indicated in the Appendix A with all the other variables. Finally, we set a proxy of risk exposures faced by the responding companies, regarding the geographic areas in which the firm is present. For French SMEs, Europe is the more common and less risky geographic areas. Because of historical relationships or cultural proximity, North America and Africa are also two zones easy to develop for French SMEs. According to French ministry of foreign trade data, all things being equal, it is harder and less frequent for french SMEs to export in Middle-East, South America or Asia because these geographic areas are more distant, geographically and/or culturally, sometimes less stable and finally riskier for French SMEs. So, we score 1 the firms which export in these areas $(n=87)$ and 0 those which only export in common geographic areas of French SMEs.

\subsection{Common method bias}

Obtaining data from a single set of participants in a certain point of time with self-report surveys is likely to cause common method bias -CMB- (Podsakoff et al., 2003). In order to overpass potential CMB, we took several ex ante steps to mitigate this risk. We embedded the questions related to our conceptual framework in a more comprehensive survey and ordered them in a way that made it almost impossible to engage in hypothesis guessing. We pretested the questionnaire and we decreased the respondents' motivation to answer the survey in a socially desirable way by assuring strict confidentiality of responses (Podsakoff et al., 2003). Then, to test for the presence of CMB effect, we first conducted Harman's single-factor test. All 17 measured variables included in our measurement model were entered into an exploratory factor analysis (EFA) using unrotated principal component analysis. We obtained four distinct factors accounting for 66.50 percent of the total variance, and the largest factor accounted for less than $50 \%$ of the variance (38.65 percent). Furthermore, only 24.3 percent of the total variance was extracted when we constrained the analysis to only one factor. Afterward, all measured variables were loaded on one factor during the confirmatory factor analysis (CFA). The results showed that this single-factor model did not fit the data properly at all $\left(\chi^{2} / \mathrm{df}=7.188 ; \mathrm{RMSEA}=0.206 ; \mathrm{CFI}=0.318 ; \mathrm{TLI}=0.220 ; \mathrm{GFI}=0.523 ; \mathrm{SRMR}=0.1942\right)$. Finally, we added a common latent factor (CLF) to our measurement model (including our control variable with latent factor, i.e. "competitive intensity"). Then, we compared the unconstrained common latent factor model (chi-square $=119.2 ; \mathrm{df}=$ 104 ) to the fully constrained (zero constrained) common latent factor model (chi-square $=142.5 ; \mathrm{df}=122$ ). We did not get a significant difference of chi-square and degree of freedom ( $p$-value $=0.179)$, indicating groups are different at the model level, so revealing no common method bias. We acknowledge that these tests could not eliminate single source bias entirely, but the information provided by these tests should help us reduce this concern.

\section{Results of the structural equation modeling}

\subsection{Evaluation of the measurement model}

Our study adopted the procedure outlined by Anderson and Gerbing (1988) for the CFA of the measurement model and for the model fit and evaluation. In particular, we used the application of the CFA procedure to study the measurement of constructs and indicators and assessed the model fit through the five evaluative index criteria required for a valid model fit, namely, the chi-square ratio, root mean square error of approximation (RMSEA), Tucker-Lewis index (TLI), comparative fit index (CFI), and goodness of fit index (GFI).

We first tested an unconstrained measurement, including our three latent variables with 39 parameters to be estimated (17 factor loading coefficients +5 covariances +17 error variances). The CFA showed a very acceptable goodness-of-fit for this measurement model: $\chi^{2} / \mathrm{df}=1.263$; RMSEA $=0.042 ; \mathrm{GFI}=.898 ; \mathrm{CFI}=0.973$; TLI $=0.967$; IFI : .974; SRMR $=0.0641$. Then, following the recommendations of Hair et al. (2010), we assessed the level of 
reliability of the indicators through Cronbach's alpha (CA) and composite reliability (CR) values to identify the relative importance of the indicators. Table 2 summarizes the results of our exploratory and confirmatory assessment of the measurement model. The values for CA and CR in each case were higher than the recommended 0.70 threshold, indicating that the scales are reliable (Bagozzi and Yi, 1988). In addition, the Average Variance Extracted (AVE coefficient) was used to assess the reliability of each construct. This coefficient serves to complement the CR measurements (Hair et al., 1998). Table 2 shows that the AVE estimates were greater than 0.50 for all concepts, indicating adequate internal reliability. Consequently, the research scales are sufficiently reliable.

Convergent validity tests were conducted to examine the proportion of variance shared by the observed variables measuring the respective unobserved variables. To do so, factor loadings were used. We consider items with factor loadings greater than 0.4 to be highly loaded on their latent variables (Hair et al., 2014). Because the factor loadings of all the indicators of the constructs are above the 0.40 threshold and are statistically significant (Table 2), convergent validity is confirmed (Hair et al., 2014).

Discriminant validity, which assesses the extent to which a compound is truly different from other compounds, was also calculated (Hair et al., 2014). According to Fornell and Larcker (1981), an acceptable confirmation of discriminant validity occurs when the AVE square root values for each compound appear greater than the correlation between constructs associated with the construct in question. The results demonstrate that AVE values are higher than the corresponding correlations in all cases (see Table 2). Moreover, the results of our CFA indicate that all of the latent variables have AVE values higher than the maximum shared variance (MSV) and the average shared squared variance (ASV) values. These two indexes confirm discriminant validity, which demonstrates that the four latent variables analyzed in the current research are distinctly different.

In addition, estimated correlations between the variables remained well below 0.70 , and all their associated variance inflation factor (VIF) values were lower than 3.0 (see Appendix B). According to Kleinbaum et al. (1988), multicollinearity problems may occur only when the VIF statistic reaches or surpasses the value of 5. Then, we do not foresee any multicollinearity problems. Overall, the measurement model fulfilled the criteria required to proceed with the evaluation of the structural model.

Note that for our model, which has 86 parameters for 147 cases, we used Soper's post hoc power calculator (2016) to assess its statistical power (Cohen et al., 2003). We obtained power values greater than 0.80 at the 0.05 level for all endogenous variables: 0.994 for the "Risk Management Practices" estimate (one predictor, observed $\mathrm{R}^{2}=0.12$ ), 0.994 for "Export Capabilities" (one predictor, including control variables, observed $\mathrm{R}^{2}=0.12$ ), 0.999 for "Foreign Direct Investments" (ten predictors, including control variables, observed $\mathrm{R}^{2}=0.35$ ), and 0.999 for "Export Turnover" (ten predictors, including control variables, observed $\mathrm{R}^{2}=0.35$ ). Thus, despite the limited number of observations, we achieve adequate statistical power to detect significant relationships between the variables.

Table 2

Measures Fiability and Reliability

\begin{tabular}{|c|c|c|c|c|c|c|c|}
\hline & & Explorator & ctor Analysis & & Confirm & ry Factor $\mathrm{Al}$ & \\
\hline & & $\begin{array}{r}66.50^{\circ} \\
\text { ex }\end{array}$ & $\begin{array}{l}\text { variance } \\
\text { ned }\end{array}$ & $\chi 2 / \mathrm{df}=1.2$ & $\begin{array}{l}\text { adjustment } \\
\text { RMSEA = } \\
0.967 ; \text { IFI }\end{array}$ & $\begin{array}{l}\text { the measure } \\
\text { 742; GFI: .8 } \\
74 \text {; SRMR }\end{array}$ & $\begin{array}{l}\text { model: } \\
\mathrm{FI}=0.973 ; \mathrm{TLI}= \\
641\end{array}$ \\
\hline Variables & Items & Loadings & $\begin{array}{l}\text { Cronbach } \\
\text { Alpha }\end{array}$ & Loadings & T-values & $\begin{array}{c}\text { Composite } \\
\text { reliability }\end{array}$ & $\begin{array}{c}\text { AVE / MSV / } \\
\text { Square of AVE }\end{array}$ \\
\hline International & RM1 & .877 & .873 & .83 & 12.503 & .874 &. $\mathbf{6 9 7 / . 2 1 5 / . 8 3 5}$ \\
\hline Risk & RM2 & .860 & & .81 & 11.157 & & \\
\hline Management & RM3 & .818 & & .87 & 11.574 & & \\
\hline Practices & & & & & & & \\
\hline Export & Cap1 & .873 & .878 & .88 & 12.775 & .881 & $. \mathbf{7 1 1} / .215 / .843$ \\
\hline Capabilities & Cap2 & .884 & & .87 & 12.664 & & \\
\hline & Cap3 & .799 & & .77 & 10.592 & & \\
\hline EPPs & Supp1_Advice & .631 & .807 & .70 & 7.743 & .830 & $.621 / .080 / .788$ \\
\hline (second order & Supp2_Training & 639 & & .70 & 7.394 & & \\
\hline factor) & Supp3_Trade_shows & .680 & & .93 & 8.806 & & \\
\hline & Supp4_Prospecting & .806 & & .69 & 11.630 & & \\
\hline & Supp5_Guarantees & .729 & & .77 & 10.171 & & \\
\hline & Supp6_Loans & .783 & & .87 & 11.151 & & \\
\hline Competitive & Comp1 & .769 & .843 & .71 & 9.153 & .844 & $. \mathbf{5 2 2} / .010 / .722$ \\
\hline intensity & Comp2 & .752 & & .69 & 8.885 & & \\
\hline & Comp3 & .797 & & .70 & 9.124 & & \\
\hline & Comp4 & .849 & & .83 & 11.401 & & \\
\hline & Comp5 & .844 & & .67 & 8.563 & & \\
\hline
\end{tabular}




\subsection{Evaluation of the structural model}

Depending on the estimator based on the maximum likelihood method that we have used, we have to establish multivariate normality (Kline, 2011). Multivariate normality was achieved for the study data. Moreover, bootstrapped parameter estimates and associated standard errors were computed for all model outputs (standardized loadings, path coefficients, and indirect effects).

Before presenting the final results, we might wonder about if whether the mediating effect of risk management is actually needed in the structural model. This can be verified by testing two different structural forms, one with the risk management variable and one without this variable. The fit without "risk management practices" is very good: $\chi^{2} / \mathrm{df}=1.351 ; \mathrm{RMSEA}=0.049 ; \mathrm{CFI}=0.962 ; \mathrm{TLI}=0.938 ; \mathrm{IFI}=.964 ; \mathrm{SRMR}=0.0702$. However, two elements claim for the global model with "risk management practices". Firstly, the fit of the model with "risk management practices" is also very acceptable and closed to the previous one: $\left(\chi^{2} / \mathrm{df}=1.520 ;\right.$ RMSEA $=0.060$ (PCLOSE: .157); CFI $=0.934 ;$ TLI $=0.904 ; \mathrm{IFI}=.937$; SRMR $=0.0877)$, proving that the model with the mediated effect shows also a good fit to the data just like the simpler formulation. Secondly, in the first model without risk, we have a slightly better fit but, above all, no significant link between "export promotion programs" and the two outcomes, i.e. foreign direct investment and export turnover. "If a model is consistent with reality, then the data should be consistent with the model. But, if the data are consistent with a model, this does not imply that the model corresponds to reality" (Bollen, 1989, p. 68). To us, this result means that the model is not consistent with the reality: EPPs would influence other elements which, in turn, finally influence the performance. This supports in itself the mediation approach and, in our case, "risk management practices" as one of these elements. Thirdly, and probably more importantly than the statistical explanation, the mediating logic has already been employed and demonstrated in previous studies on the topic: for instance, Catanzaro et al. (2018) or Leonidou et al. (2011). For these authors employing, as we did, the RBV as a conceptual framework, EPPs influence some resources and capabilities of the SMEs which, in turn, influence the international performance. By choosing the same framework, path, and theoretical arguments, we hope to add new insights in this stream of research. In other terms, we consider the EPPs effect on international performance as purely indirect. The results below fully support this view.

We provide the results of the hypothesized structural model in Table 3. The correlation matrix (Appendix B) showed acceptable correlation indexes between the variables. Moreover, the structural model achieved an acceptable goodness-of-fit as presented above.

Table 3

Summary of results of hypothesis testing

\begin{tabular}{|c|c|c|c|}
\hline \multirow[t]{2}{*}{ Path } & \multicolumn{2}{|c|}{ Standardized coefficient } & \multirow{2}{*}{ Result } \\
\hline & $\begin{array}{c}\text { ML } \\
\text { Estimates a }\end{array}$ & Bootstrap Estimates ${ }^{b}$ & \\
\hline H1: EPPs $\rightarrow$ Export capabilities & $.341^{* * *}, \mathrm{p}=.003$ & $.182-.678, \mathrm{p}=.002$ & Supported \\
\hline $\begin{array}{l}\mathrm{H} 2: \mathrm{EPPs} \rightarrow \text { International risk } \\
\text { management practices }\end{array}$ & $.348^{* * *}, p=.003$ & $.173-.568, \mathrm{p}=.006$ & Supported \\
\hline $\begin{array}{l}\text { H3: Export capabilities } \rightarrow \text { Export } \\
\text { turnover }\end{array}$ & $.345^{* * * *}, p=.000$ & $.211-.491, p=.005$ & Supported \\
\hline $\begin{array}{l}\text { Export capabilities } \rightarrow \text { Foreign Direct } \\
\text { Investments }\end{array}$ & $.117, \mathrm{~ns}$ & $-.045-.283, p=.233$ & Not supported \\
\hline $\begin{array}{l}\text { H4: International risk management } \\
\text { practices } \rightarrow \text { Export turnover }\end{array}$ & $.056, \mathrm{~ns}$ & $-.116-.180 \mathrm{p}=.635$ & Not supported \\
\hline $\begin{array}{l}\text { International risk management } \\
\text { practices } \rightarrow \text { Foreign Direct } \\
\text { Investments }\end{array}$ & $.243^{* * *}, p=.003$ & $089-417, p=.019$ & Supported \\
\hline \multicolumn{4}{|l|}{ Control variables effects } \\
\hline $\begin{array}{l}\text { Size } \rightarrow \text { FDI } \\
\text { Size } \rightarrow \text { Export turnover }\end{array}$ & & $\begin{array}{l}.150 \\
-.083\end{array}$ & \\
\hline
\end{tabular}


Age $\rightarrow$ FDI

Industry $\rightarrow$ FDI $.143 *$

Industry $\rightarrow$ Export turnover $\quad .084$

Family firms $\rightarrow$ FDI $\quad-.099$

Family firms $\rightarrow$ Export turnover $\quad-.127^{*}$

International experience $\rightarrow$ FDI $.236^{*}$

International experience $\rightarrow$ Export turnover $\quad .147$

Competitive intensity $\rightarrow$ FDI $.118^{* *}$

Competitive intensity $\rightarrow$ Export turnover $\quad-.037$

Risk exposures $\rightarrow$ FDI $\quad .030$

Risk exposures $\rightarrow$ Export turnover $\quad .349 * *$

$* \mathrm{p}<.1, * * \mathrm{p}<.05, * * * \mathrm{p}<.01, * * * * \mathrm{p}<.001$

${ }^{a}$ Maximum Likelihood estimates and associated p-value.

${ }^{\mathrm{b}}$ Bootstrapped $90 \%$ confidence intervals (Bias-corrected percentile method) and corrected p-value.

ns: non-significant

As hypothesized, we identified a significant influence of EPPs on export capabilities $(\mathrm{H} 1 ; \beta=0.341 * * * ; p=$ $0.003)$, and on international risk management practices $\left(\mathrm{H} 2 ; \beta=0.348^{* * *} ; \mathrm{p}=0.003\right)$. Then, export capabilities influence the export turnover $\left(\mathrm{H} 3 ; \beta=0.345^{* * * * ;} \mathrm{p}=0.000\right)$ but not the foreign direct investments, whereas international risk management practices influence foreign direct investments $(\mathrm{H} 4 ; \beta=0.243 * * * \mathrm{p}=0.003)$ but not the export turnover. The hypotheses $\mathrm{H} 3$ and $\mathrm{H} 4$ are only partially supported depending on how international performance is captured. As shown in table 3, in terms of control variables, age and competitive intensity on FDI and risk exposures on export turnover are significant to the $5 \%$ level, but several are to the $10 \%$ level (industry, family firms, and international experience).

When we examined AMOS's effect decomposition statistics, we found no direct influence of EPPs on export turnover and foreign direct investment, but a statistically significant indirect effect of EPPs on both, the export turnover $\left(\gamma=0.137^{* * *}\right.$, bootstrapped $90 \%$ confidence interval $=0.069-0.313$, corrected $\mathrm{p}$-value $\left.=0.004\right)$ and foreign direct investments $\left(\gamma=0.125^{* * *}\right.$, bootstrapped 90\% confidence interval $=0.073-0.246$, corrected $\mathrm{p}$-value $\left.=0.006\right)$. Consequently, EPPs allow the firm to improve its export capabilities and risk management practices, which in turn increases its export turnover and foreign direct investments. So, our results claim for a purely indirect effect of EPPs on international outcomes.

Figure 2 shows the structural model with the final significant results.

Figure 2

Structural model with factor loadings

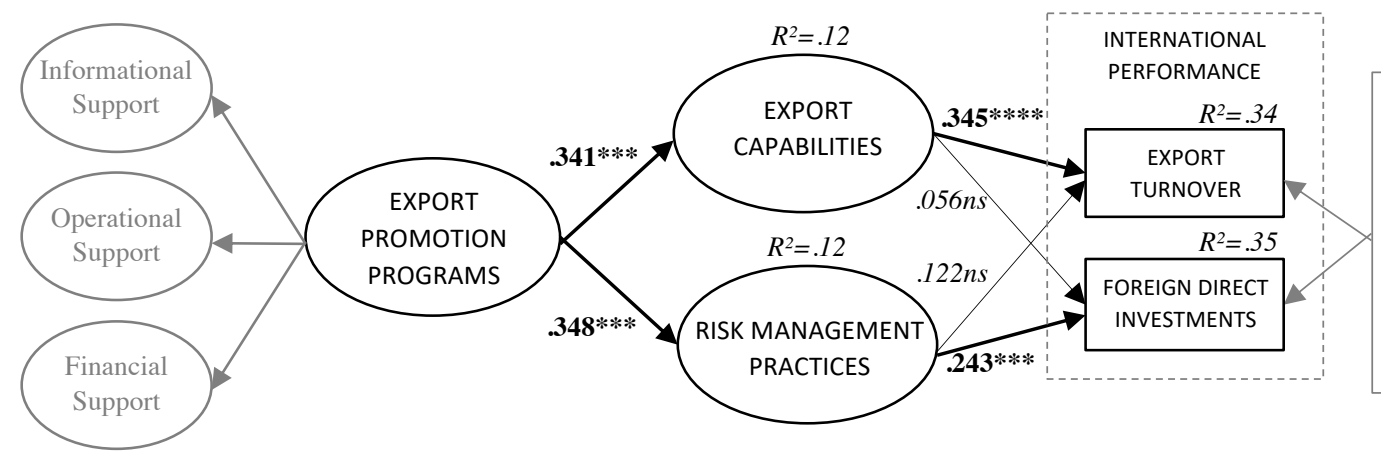

CONTROL VARIABLES:

4.3. Robustness Tests 
We also conducted several robustness tests. First, we conducted an analysis to see what happens if the very small companies (45.6\% of the sample) are left out, or if the results between small and medium firms are directly confronted (multi-groups analysis). First, we excluded the very small firms (with less than 10 employees) and focused on the medium firms $(\mathrm{n}=85)$. We tested the statistical power of the model (Cohen et al., 2003) without the microfirms. As with the global sample, we obtained power values greater than 0.80 at the 0.05 level for all the endogenous variables: 0.827 for "risk management practices" estimate, 0.867 for "export capabilities" estimate, 0.999 for "export turnover", and 0.999 for "foreign direct investments". The path coefficients of the structural model went to the exact same direction than with the global sample. Second, we tested the structural model on the two groups and conducted a multi-groups analysis. We only identify a stronger positive impact of "export capabilities" on "export turnover" for the medium firms, but the effect on the small one is also positively significant. We can conclude EPPs influence on export capabilities and risk management practices, and of the latter on international performance, are not affected by the very small size of the firm.

Second, in each structural model analysis we tested with different measures of the industry effet (once with 'computer and scientific services industry' versus others, once with 'other services industry' versus others, once with 'agro-industry versus others, and once with 'manufacturing industry' versus others), we found the same results on our hypothesis, and only a slight significant effect at the $10 \%$ level of manufacturing industries.

Finally, to challenge the mediating approach of our conceptual model, and following a suggestion from one of the reviewer, we decided to test an alternative model with risk management practices as moderator, considering that one can believe EPPs-performance relationship would be impacted (moderation effect) by the degree of risk management practices, with, for instance, the firms with a better capability enjoying more of the EPPs used. Actually, our complementary analysis found no moderating role of risk management practices on the EPPs - international performance relationship, with both a not significant effect of the interaction variable on export turnover $(\beta=-0.348$ $\mathrm{ns} ; \mathrm{p}=0.138)$, and on foreign direct investments $(\beta=0.006 \mathrm{~ns} ; \mathrm{p}=0.953)$. These additional analyses reinforce the mediating approach, at least with the internal capabilities we studied in this article. However, we recognize moderation effect could be a relevant topic for the field. But we consider risk management practices is not the relevant variable in that perspective.

\section{Discussion}

This study presents a conceptual model intended to test the relationships among EPPs, export capabilities, international risk management practices and SMEs' international performance. Our findings support the mediation effect of export capabilities and risk management practices, allowing for a precise and better understanding of the relationship between EPPs and international outcomes. These results provide several theoretical and methodological contributions on the one hand and managerial contributions and policy makers recommendations on the other hand. They also invite us to highlight some methodological limitations and directions for future research.

\subsection{Theoretical and methodological contributions}

From a theoretical perspective, our conceptual model - studying public support, export capabilities, risk management and international performance together - adds one more straw to the "support - resources - performance" relationship. Because the level of perceived and realized international risk explains, respectively, the decision of the manager to go international or not, and the success of the strategy implemented, risk is a widely used concept in theoretical and empirical studies on the firm's internationalization strategy (Figueira de Lemos et al., 2011). We could have expected to find more studies demonstrating the challenges of risk management capability in internationalized companies, and the specific role of public programs on the need for reinforcement of this type of capability, especially in the SME context. Previous studies on EPPs demonstrated how public supports help the firm acquire new resources needed for successful international development, such as foreign market knowledge, marketing competencies, network or social relationships (Fang et al., 2007; Francis and Collins-Dodd, 2004; Leonidou et al., 2011; Catanzaro et al., 2018; Spyropoulou et al., 2018). The comprehensive study of Leonidou et al. (2011) offers a very broad view of the relationship between EPPs and performance, integrating several types of resources and capabilities. Very recently, on a sample of 95 internationalized SMEs, Malca et al. (2019) also found that EPPs help the firm to reinforce some managerial and intellectual resources. But to our knowledge, risk management practices have never been empirically demonstrated as strategic resources allowing to better understand the relationship between international public support and firm performance.

Then, our results support an indirect effect of EPPs on the international performance, through the capabilities of the firm. The association between the use of these programs and firm performance is not direct, but rather is achieved through an enhancement of the firm's capabilities required to operate internationally. Thus, the gain of new or reinforced capabilities through the support received strengthens the international performance. Putting things differently, in considering, today, two companies with the same level of export capabilities and risk management practices, the one which will be supported by EPPs should have in the future better capabilities and, then, a better 
international performance. Indeed, by motivating the firm to go international, by helping it to better understand foreign markets, identify opportunities, meet key players, and better identify risks; by giving to the firm valuable knowledge about the foreign markets targeted; by allowing it to participate into trade shows and prospecting missions to gain experience; by financing a part of its international activity, helping it to acquire other resources, and by covering some risks, the export support services act positively on the internal capabilities of the SME. Nevertheless, in accordance with the RBV which suggests a holistic view of the firm in which the coordinated deployment of resources and capabilities provides to the internationalized SME the foundation for creating, producing, and marketing products (Young et al., 2000), this is not the fact to have strong export capabilities and risk management practices in themselves which allows the firm to be more successful internationally. Our results by which export capabilities and risk management practices, as internal factors improved by EPPs, positively influence the international performance of the firm could be explained by the fact that these capabilities allow the firm to develop a specific collection of organizational strategies which will be the foundation of the international performance (Leonidou et al., 2011). This echos the VRIO framework which stipulate that the performance is determined by the quality of the resources and capabilities of the firm and the way the firm uses them (Barney, 2007). In that way, to use EPPs in order to develop or improve some internal capabilities valuable, rare and hard to imitate, will have an impact on performance because the firm will use these capabilities to design the right strategy to exploit its potential and meet the markets requirements (Spyropoulou et al. 2017).

Another implication of our findings is related to the international performance factors analysed in this article. Most studies about EPPs effectiveness focused on the economic aspect of international performance (Catanzaro et al., 2018) and provided contradictory results about their direct or indirect influences on performance (Faroque and Takahashi, 2012). Our modelization provides a better understanding of this relationship by distinguishing between export turnover as an economic measure, and foreign direct investments as a strategic measure. We show that all the capabilities impacted by EPPs do not influence all the aspects of international performance, which suggests that future studies on EPPs effectiveness could capitalize on a more accurate measure of international performance. Specifically, we show that export capabilities have a significant impact only on the firm export turnover (H3), whereas risk management practices have a significant impact only on the FDI (H4). The partial evidence for H3 and H4 can be explained by the two different ways to operationalize international performance. An obvious difference between export turnover as an economic measure and foreign direct investment as a strategic measure is the different time horizon of both measures. Indeed, if the international development efforts of the firm can quickly provide an export turnover, even modest, the foreign direct investments are, by essence, more complex and long to deploy. We can therefore think that depending on the nature of the capabilities that the company develops, the impact will be visible in the more or less long term. Putting in place FDI supposes more sustainable capacities which change fundamentally the internal practices of the firm (which is the case of risk management practices), while increasing the turnover requires capabilities that could be more temporary or linked to rapid targeting of market potential. Ultimately, assuming that FDI is a strategic performance measure due to the competitive advantages that this mode of presence abroad provides (Doukas and Lang, 2003; Dominguez, 2018), these results reinforce the interest of EPPs for SMEs. These supports play in favor of a diversification of international entry methods, inducing a diversification of international risks likely to reduce the overall risk incurred.

From a methodological perspective, our study highlights with a quantitative study the crucial role of risk management practices in international studies and what can be levers (public supports) and outcomes (performance). By showing how SMEs are able to acquire new resources from external institutions delivering EPPs, our study sheds greater light on the origins of resources (Barney et al., 2011). Thus, public institutions delivering some supports could be considered as a pool of resources for companies. This supports the view that government assistance acts as an "external resource," which, if properly used, helps small firms alleviate deficiencies that hinder international development (Seringhaus 1986). To our knowledge, no quantitative study has been conducted to test, with a statistical method, the specific role of public support on risk management practices and the mediating effect of this variable on international performance.

\subsection{Managerial contributions and recommendations for policymakers}

On the one hand, our study allows us to formulate contributions intended for SME managers who want to develop their company internationally, while and managing and overcoming international risks incurred. First, it stresses valuable role of export promotion programs in helping business managers ultimately achieve superior performance in foreign markets. In this, our results confirm many empirical studies already conducted (Leonidou et al., 2011; Filipe-Lages et Montgomery, 2005; Catanzaro et al., 2018; Malca et al., 2019). Thus, managers should investigate the full range of these programs, carefully evaluate the programs' content, and select programs that are suitable for their particular case and their specific international venture (Leonidou et al., 2011). This invites to a closer communication with public agencies responsible for providing supports will help increase familiarity with the 
programs offered and appreciation of their usefulness. Our results could also help managers to make some recommendations to their public adviser to design and offer suitable and useful international programs. Second, the major contribution of this research is related to the crucial role of EPPs on the risk management practices. Multiple risks are involved in having an international presence, which can be added on top of traditional business risks. These risks are often new for the smallest and youngest firms and are fundamentally difficult to manage efficiently (Oviatt et al., 2004). SMEs' constraints regarding financial and non-financial resources reinforce this difficulty, and the financial impacts of these risks could be very dangerous for the firm's sustainability. Managers need to be aware that their organization could take advantage of the public supports they have solicited, because these supports have a positive impact on the firm's organizational capabilities, in a field which is not only linked to the company's ability to increase its international presence, but also to secure the development strategy using internal practices.

On the other hand, demonstrating that public policies can provide new strategic resources -i.e., export capabilities and risk management capabilities- to SMEs in their internationalization strategy and lead them to greater performance is a major challenge of governments' support choices, especially in the context of public financial rationing (Clarysse et al., 2009; Bannõ et al., 2014). In France as in most countries, small and medium sized enterprises make up a large part of the wealth and contribute to the dynamism of the national economy. The challenge for today's governments is the development of appropriate measures aimed at reducing market failures, uncertainty, and risks, and at helping these firms to acquire and/or develop the resources needed for their internationalization. SMEs are critical to the competitiveness of advanced, industrialised countries, and their growth is driven by many factors among which internationalization plays a significant role (Love and Roper, 2015; Belhoste et al., 2019). Since relatively few SMEs have the ability to maintain international operations sustainably over time, particularly in distant markets, there is a great concern for policymakers to stimulate their international expansion. Even if public and private support for the internationalisation of SMEs has increased significantly in France over the past 20 years, it is reasonable to doubt the effectiveness of these policies (Belhoste et al., 2019). Our empirical results confirm that public policies could provide some strategic capabilities, as risk management is considered in the current economic and competitive context. In the context of public financial rationing in France, the effectiveness of EPPs is especially relevant (Freixanet, 2012), and our study reaffirms the need for government policy makers to continue their export-promotion policies in an effort to help small firms carry out their international operations more effectively and efficiently. In this sense, policymakers responsible for the design of EPPs should include programmes aimed at the development non only export capabilities, but also internal risk management capabilities. In this sense, EPPs' agents should identify firm-level gaps between the resource base of the SMEs and the required resources and capabilities to compete in foreign markets while securising the risks incurred (Malca et al., 2019). This could suggest a necessary adaptation of the programs to companies' requirements to fit with their pragmatic needs and stimulate the development of more structured risk management practices. Furthermore, our results could have a positive effect on the program's credibility in the eyes of public opinion and governments that finance them, and the importance of giving managers information about the organizational role that these programs can play in their organizations (Freixanet, 2012).

\subsection{Limitations and directions for future research}

Despite the contributions of this work, the results of this study need to be interpreted with caution and considering some limitations, which also represent some relevant directions for future research.

In the method section, a limitation remains regarding the use of cross-sectional data to test the mediating relationship of export capabilities and risk management practices on the support-performance relationships. The strength of this relationship can vary slightly across industries (Nason and Wiklund, 2018), although we have taken into account the industry as a control variable in our conceptual model. Another methodological limitation relies on the scale measurement of risk management practices we used, as it comes from Subramaniam et al. (2011) who designed a broader scale for measuring risk management formalization, integrating risk management practices but also others factors as the embeddedness of risk management in organization's culture or the effectiveness of the risk management policy, and which was particularly relevant for bigger companies. Although we only focused on the items related to risk management practices, we adapted them to the international context, and we got very good fiability and reliability, we could expect that a scale measurement specifically design for international risk management in SMEs could provide more accurate results.

Further, in line with Belhoste et al. (2019), it could also be interesting to consider in our model the stage of internationalization of the firm (entrance or intensification) to see the extent to which EPPs, risk management practices and export capabilities play a different role according to the different stages. Future studies should also address the moderating role of the dynamic capabilities of the firm, i.e. their capacity "to integrate, build, and reconfigure internal and external resources/competences to address, and possibly shape, rapidly changing business environments" (Teece 2012, p. 1395). To date, only static resources and capabilities (Lockett et al., 2009) have been studied in EPPs impact modelizations. As dynamic capabilities are particularly relevant in dynamic and risky environments such as international markets (Al-Aali et Teece, 2014), companies with more dynamic capabilities could be in better shape 
for taking advantage of EPPs and exploiting international opportunities. Furthermore, as Leonidou et al. (2011) did, we could integrate in our modelization another strategic decision variable to better explain the link between export capabilities and export turnover, for instance export marketing strategy, in order to demonstrate that augmented organizational resources and capabilities are also conducive to developing an effective strategy that matches international opportunities. The implementation of this strategy would help firms achieve advantages over the competition and offer greater value to overseas customers, what the RBV and VRIO frameworks underpin.

In line with Gordon and al. (2009), we also think it would be appropriate, in order to go deeper on the comprehension of the risk management-firm performance relationship, to test the contingency of different factors affecting a firm, like environmental uncertainty, industry competition, firm size, firm complexity, and board of directors' monitoring.

Finally, as another perspective for research, an interesting research project would be to conduct an empirical study in several countries to assess whether our results can be generalized. Indeed, we cannot exclude some specificities of the French context for both the EPPs and the internationalized SMEs. In that regards, future studies should contribute to the literature through evidence from emerging economies (Malca et al., 2019).

\section{Conclusion}

In conclusion, our study offers a number of novel empirical findings regarding the influences of EPPs on organizational capabilities of internationalized SMEs. It also provides new insights on the enablers and the influences of risk management practices in the context of SME internationalization. Specifically, we find that the degree of use of export promotion programs shapes the export capabilities and the risk management practices toward internationalization and, ultimately, positively influences the international performances of the SME. We hope that this study's finding will stimulate further exploration of the linkages between EPPs, internal resources and capabilities and key strategic outcomes for organizations, especially SMEs.

\section{Acknowledgements}

We thank the anonymous reviewers of SBEJ that have significantly improved the paper thanks to their insightful and constructive comments.

\section{References:}

Acs, Z. J., Morck, R., Myles Shaver, J., Yeung, B, 1997. The Internationalization of Small and Medium-Sized Enterprises: A Policy Perspective. Small Business Economics, 9, 7-20. doi.org/10.1023/A:1007991428526

Al-Aali, A., Teece, D.J.. 2014. International Entrepreneurship and the Theory of the (Long-Lived) International Firm: A Capabilities Perspective. Entrepreneurship Theory and Practice, Special Issue: International Entrepreneurship, 38(1), 95-116. doi.org/10.1111/etap.12077

Ahmed, Z. U., Mohamad, O., Tan, B., Johnson, J. P., 2002. International risk perceptions and mode of entry: a case study of Malaysian multinational firms. Journal of Business Research, 55(10), 805-813. doi.org/10.1016/S01482963(00)00220-4

Amankwah-Amoah, J., Wang, X., 2019. Opening editorial: contemporary business risks: an overview and new research agenda. Journal of Business Research, 97, 208-211. doi.org/10.1016/j.jbusres.2019.01.036

Anderson, J. C., Gerbing, D. W., 1988. Structural equation modeling in practice: A review and recommended twostep approach. Psychological Bulletin, 103(3), 411-423. doi.org/10.1037/0033-2909.103.3.411

Aureli, S., Salvatori, F., 2013. The current state of risk management in Italian small and medium-sized enterprises. Proceedings of the 8th International Conference Accounting and Management Information Systems, AMIS, June $12-$ 13, Roumanie. doi.org/10.6092/unibo/amsacta/3947

Bagozzi, R. P., Yi, Y., 1988. On the evaluation of structural equation models. Journal of the Academy of Marketing Science, 16(1), 74-94. doi.org/10.1007/BF02723327

Bannò, M., Piscitello, L., Varum, C., 2014. The Impact of Public Support on SMEs' Outward FDI: Evidence from Italy. Journal of Small Business Management, 52(1), 22-38. doi: 10.1111/jsbm.12029

Barney, J.B., 1991. Firm resources and sustained competitive advantage. Journal of Management, 17(1), p. 99-120. doi.org/10.1177/014920639101700108

Barney, J.B., 2007. Resource-Based Theory: Creating and Sustaining Competitive Advantage. OUP Oxford, 2007, 316 pages. ISBN-10: 0199277699

Barney, J.B., Ketchen, Jr, D. J., Wright, M., 2011. The future of resource-based theory: revitalization or decline? Journal of Management, 37(5), 1299-1315. doi.org/10.1177/0149206310391805 
Becchetti, L., Trovato, G., 2002. The determinants of growth for small and medium sized firms. The role of the availability of external finance. Small Business Economics, 19(4), 291-306. doi.org/10.1023/A:1019678429111

Belhoste, N., Bocquet, R., Favre-Bonté, V., Bally, F., 2019. How do SMEs use support services during their internationalisation process: A comparative study of French traditional SMEs and INVs in Asia. International Small Business Journal, 37(8), 804-830. doi.org/10.1177/0266242619871165

Bentejac, A., Desponts, J., 2013. Report of the French Senate, Modernisation of public policy - Evaluation mission on the effectiveness of the support system for the internationalisation of the French economy (june 2013), 68 pages. https://www.modernisation.gouv.fr/sites/default/files/fichiers-attaches/epp_internationalisation

economie.pdf

Bérard, C., Teyssier, C., 2017. Risk Management: Lever for SME Development and Stakeholder Value Creation. ISTE Ltd and John Wiley \& Sons. ISBN: 978-1-786-30165-9

Birru, W., Runhaar, P., Zaalberg, R., Lans, T. M. 2018. Explaining Organizational Export Performance by Single and Combined International Business Competencies. Journal of Small Business Management, 57(3), $1172-1192$. doi.org/10.1111/jsbm. 12403

Bollen, 1989, p. 68, Structural Equation with latent variables.New York, NY: Wiley. ISBN-10: 0471011711

Bromiley, P., McShane, M., Nair, A., Rustambekov, E., 2015. Enterprise Risk Management: Review, critique, and research directions. Long Range Planning, 48(4), 265-276. doi.org/10.1016/j.1rp.2014.07.005

Broocks, A., Van Biesebroeck, J. (2017). The impact of export promotion on export market entry. Journal of International Economics, 107(July), 19-33. doi.org/10.1016/j.jinteco.2017.03.009

Brustbauer, J., 2014. Enterprise risk management in SMEs: Towards a structural model. International Small Business Journal, 34(1), 70-85. doi.org/10.1177/0266242614542853

Busse, C., Mahlendorf, M. D., Bode, C., 2016. The ABC for studying the too-much-of-a-good-thing effect: A competitive mediation framework linking antecedents, benefits, and costs. Organizational Research Methods, 19(1), 131-153. doi.org/10.1177/1094428115579699

Cabrol, M., Nlemvo, F., 2012. Diversité de comportement des entreprises à internationalisation précoce et rapide: essai de validation d'une typologie. Revue de l'Entrepreneuriat (Review of Entrepreneurship), 11(3), 111-136. doi.org/10.3917/entre.113.0111

Calof, J. L., Beamish, P. W. 1995. Adapting to foreign markets: Explaining internationalisation. International Business Review, 4(2), 115-131. doi.org/10.1016/0969-5931(95)00001-G

Casson, M., da Silva Lopes, T., 2013, Foreign direct investment in high-risk environments: an historical perspective. Business History, 55(3), 375-404. doi.org/10.1080/00076791.2013.771343

Catanzaro, A., Messeghem, K., Sammut, S., 2018. Effectiveness of export support programs: impact of the relational capital and international performance of early internationalizing small businesses. Journal of Small Business Management. doi.org/10.1111/jsbm.12489

Catanzaro, A., Messeghem, K., Sammut, S., 2015. Impact of export support: A conceptual model for export start-ups. International Management, 19(2), 177-196. doi.org/10.7202/1030397ar

Clarysse, B., Wright, M., Mustar, P., 2009. Behavioural additionality of R\&D subsidies: A learning perspective. Research Policy, 38(10), 1517-1533. doi.org/10.1016/j.respol.2009.09.003

Chrisman, J. J., McMullan, E., Hall, J., 2005. The influence of guided preparation on the long-term performance of new ventures. Journal of Business Venturing, 20(6), 769-791. doi.org/10.1016/j.jbusvent.2004.10.001

Cohen, J., Cohen, P., West, S. G., Aiken, L. S., 2003. Applied multiple regression. Correlation Analysis for the Behavioral Sciences, third ed. Mahwah, NJ: Lawrence Earlbaum Associates. ISBN-10: 0805822232

COSO, 2004. Enterprise Risk Management - Integrated Framework, Committee Of Sponsoring Organizations of the Treadway Commission, vol. 2. https:/www.coso.org/Documents/COSO-ERM-Executive-Summary.pdf

Cumming, D., Fischer, E., Peridis, T., 2015. Publicly funded business advisory services and entrepreneurial internationalization. International Small Business Journal, 33(8), 824-839. doi.org/10.1177/0266242614537849

Davila, A., Foster, G., Oyon, D., 2009. Accounting and control, entrepreneurship and innovation: Venturing into new research opportunities. European Accounting Review, 18(2), 281-311. doi.org/10.1080/09638180902731455

De Maeseneire, W., Claeys, T., 2012. SMEs, foreign direct investment and financial constraints: The case of Belgium. International Business Review, 21(3), 408-424. doi.org/10.1016/j.ibusrev.2011.03.004

Dhanaraj, C., Beamish, P. W., 2003. A resource-based approach to the study of export performance. Journal of Small Business Management, 41(3), 242-261. doi.org/10.1111/1540-627X.00080

Dimitratos, P., Johnson, J. E., Plakoyiannaki, E., Young, S. (2016). SME internationalization: How does the opportunity-based international entrepreneurial culture matter?. International Business Review, 25(6), 1211-1222. doi.org/10.1016/j.ibusrev.2016.03.006

Dominguez, N., 2018. Promotion agencies and SMEs' internationalization process: A blessing or a curse? Journal of International Entrepreneurship, 16(1), 58-81.doi.org/10.1007/s10843-017-0219-y 
Doukas, J., Lang, L., 2003. Foreign direct investment, diversification and firm performance. Journal of International Business Studies, 34(2), 153. doi.org/10.1057/palgrave.jibs.8400014

Eriksson, K., Jonsson, S., Lindbergh, J., Lindstrand, A., 2014. Modeling firm specific internationalization risk: An application to banks' risk assessment in lending to firms that do international business. International Business Review, 23(6), 1074-1085. doi.org/10.1016/j.ibusrev.2014.06.011

Falkner, E. M., Hiebl, M. R., 2015. Risk management in SMEs: a systematic review of available evidence. The Journal of Risk Finance, 16(2), 122-144. doi.org/10.1108/JRF-06-2014-0079

Fang, Y., Wade, M., Delios, A., Beamish, P. W., 2007. International diversification, subsidiary performance, and the mobility of knowledge resources. Strategic Management Journal, 28(10), 1053-1064. doi.org/10.1002/smj.619

Faroque, E. R., Takahashi, Y., 2012. "Export Assistance: The Way and Forward," Springerbriefs in Business, 88 pages. doi.org/10.1007/978-1-4614-1296-0_1

Farrell, M., Gallagher, R., 2015 . The valuation implications of enterprise risk management maturity. Journal of Risk and Insurance, 82(3), 625-657. doi.org/10.1111/jori.12035

Filipe-Lages, L., Montgomery, D. B., 2005. The relationship between export assistance and performance improvement in Portuguese export ventures: An empirical test of the mediating role of pricing strategy adaptation. European Journal of Marketing, 39(7/8), 755-784. doi.org/10.1108/03090560510601752

Figueira-de-Lemos, F., Johanson, J., Vahlne, J. E., 2011. Risk management in the internationalization process of the firm: A note on the Uppsala model. Journal of World Business, 46(2), 143-153. doi.org/10.1016/j.jwb.2010.05.008

Fornell, C., Larcker, D. F., 1981. Evaluating structural equation models with unobservable variables and measurement error. Journal of Marketing Research, 18(1), 39-50. doi.org/10.1177/002224378101800104

Francis, J., Collins-Dodd, C., 2004. Impact of export promotion programs on firm competencies, strategies and performance: The case of Canadian high-technology SMEs. International Marketing Review, 21(4/5), 474-495. doi.org/10.1080/00076791.2013.771343

Freixanet, J., 2012. Export promotion programs: Their impact on companies' internationalization performance and competitiveness. International Business Review, 21, 1065-1086. https://doi.org/10.1016/j.ibusrev.2011.12.003

Gao, S. S, Sung, M.C., Zhang, J, 2011. Risk management capability building in SMEs: a social capital perspective. International Small Business Journal, 31(6), 677-700. doi.org/10.1177/0266242611431094

Gençtürk, E.F., Kotabe, M., 2001. The effect of export assistance program usage on export performance: a contingency explanation. Journal of International Marketing, 9(2), 51-72. doi.org/10.1509/jimk.9.2.51.19886

Gordon, L. A., Loeb, M. P., Tseng, C., 2009. Enterprise risk management and firm performance: A contingency perspective. Journal of Accounting and Public Policy, 28, 301-327. doi.org/10.1016/j.jaccpubpol.2009.06.006

Hair, J. F., Tatham, R., Anderson, R. E., Black, W., 1998. Multivariate data analysis, $5^{\text {th }}$ ed. Upper Saddle River: Prentice Hall. ISBN-10: 0138948585

Hair, J. F., Black, W. C., Babin, B. J., Anderson, R. E., 2010. Multivariate data analysis, $7^{\text {th }}$ ed. Englewood Cliffs: Prentice Hall. ISBN-10: 0138132631

Hair, J., Sarstedt, M., Hopkins, L., G. Kuppelwieser, V., 2014. Partial least squares structural equation modeling (PLSSEM) - An emerging tool in business research. European Business Review, 26(2), 106-121. doi.org/10.1108/EBR-102013-0128

Haans, R. F., Pieters, C., He, Z. L., 2016. Thinking about U: Theorizing and testing U-and inverted U-shaped relationships in strategy research. Strategic Management Journal, 37(7), 1177-1195. doi.org/10.1002/smj.2399

Helfat, C. E., Peteraf, M. A., 2003. The dynamic resource-based view: Capability lifecycles. Strategic management journal, 24(10), 997-1010. doi.org/10.1002/smj.332

Henschel, T., 2006. Risk management practices in German SMEs: an empirical investigation. International Journal of Entrepreneurship and Small Business, 3(5), 554-571. doi: 10.1504/IJESB.2006.010543

Henschel, T., 2010. Typology of risk management practices: an empirical investigation into German SMEs. International Journal of Entrepreneurship and Small Business, 9 (3), 264-294. doi: 10.1504/IJESB.2010.031922

Hilmersson, M., 2014. Small and medium-sized enterprise internationalisation strategy and performance in times of market turbulence. International Small Business Journal, 32(4), 386-400. doi.org/10.1177/0266242613497744

Hoyt, R. E., Liebenberg, A. P., 2011. The value of enterprise risk management. Journal of Risk and Insurance, 78(4), 795-822. doi.org/10.1111/j.1539-6975.2011.01413.x

Jayathilake, P. M. B., 2012. Risk management practices in small and medium enterprises: Evidence from Sri Lanka. $\begin{array}{llll}\text { International Journal of } & \text { Multidisciplinary } & \text { Research, } & \text { 2(7), }\end{array}$ https://www.researchgate.net/publication/267200905 RISK_MANAGEMENT_PRACTICES_IN_SMALL_AND_ MEDIUM ENTERPRISES_EVIDENCE_FROM_SRI_LANKA

Johanson, J., Vahlne, J. E., 1977. The internationalization process of the firm. Journal of International Business Studies, 8, 23-32.doi.org/10.1057/palgrave.jibs.8490676

Johanson, J., Vahlne, J. E., 2009. The Uppsala internationalization process model revisited: From liability of foreignness to liability of outsidership. Journal of International Business Studies, 40(9), 1411-1431. doi.org/10.1057/jibs.2009.24 
Kaleka, A., 2002. Resources and capabilities driving competitive advantage in export markets: guidelines for industrial exporters. Industrial Marketing Management, 31(3), 273-283.doi.org/10.1016/S0019-8501(00)00148-6

Katsikeas, C. S., Leonidou, L. C., Morgan, N. A., 2000. Firm-level export performance assessment: review, evaluation, and development. Journal of the Academy of Marketing Science, 28(4), 493-511. doi.org/10.1177/0092070300284003

Kleinbaum, D.G., Kupper, L.L., Muller, K.E., 1988. Applied regression analysis and other multivariable methods. Boston: PWS-KENT Publishing Company. ISBN-10: 0871501236

Kline, R. B., 2011. Principles and practice of structural equation modeling, 3rd ed., New York, Guilford publications. ISBN-10: 1606238760

Kraus, S., Ambos, T. C., Eggers, F., Cesinger, B., 2015. Distance and perceptions of risk in internationalization decisions. Journal of Business Research, 68(7), 1501-1505. doi.org/10.1016/j.jbusres.2015.01.041

Kuivalainen, O., Saarenketo, S., Puumalainen, K., 2012. Start-up patterns of internationalization: A framework and its application in the context of knowledge-intensive SMEs. European Management Journal, 30, 372-385. doi.org/10.1016/j.emj.2012.01.001

Lages, L. F., Montgomery, D., 2005. The relationship between export assistance and performance improvement in Portuguese export ventures: an empirical test of the mediating role of pricing strategy adaptation. European Journal of Marketing, 39(7-8), 755-784. doi.org/10.1108/03090560510601752

Lederman, D., Olarreaga, M., Payton, L., 2010. Export promotion agencies: Do they work? Journal of Development Economics, 91(2), 257-265. doi.org/10.1016/j.jdeveco.2009.09.003

Leonidou, L. C., Palihawadana, D., Theodosiou, M., 2011. National export-promotion programs as drivers of organizational resources and capabilities: effects on strategy, competitive advantage, and performance. Journal of International Marketing, 19(2), 1-29. doi.org/10.1509/jimk.19.2.1

Leonidou L. C., Samiee S., and Geldres-Weiss V. V., 2015. Using National Export Promotion Programs to Assist Smaller Firm's International Entrepreneurial Initiatives, In Handbook of Research on International Entrepreneurship Strategy: Improving SME Performance Globally.Publisher: Edward Elgar Publishing Ltd.Editors: Ghauri, P.N. and Kirpalani, V.H.M. doi.org/10.4337/9781783471584.00023

Lisboa, A., Skarmeas, D., Lages, C., 2011. Entrepreneurial orientation, exploitative and explorative capabilities, and performance outcomes in export markets: A resource-based approach. Industrial marketing management, 40(8), 12741284. doi.org/10.1016/j.indmarman.2011.10.013

Lloyd-Reason, L., Ibeh, K., Deprey, B., 2009. Top barriers and drivers to SME internationalisation. Report by the OECD Working Party on SMEs and Entrepreneurship, OECD. http://www.oecd.org/cfe/smes/43357832.pdf

Lockett A., Thompson S., Morgenstern U., 2009. The development of the resource-based view of the firm: A critical appraisal. International Journal of Management Reviews, 11(1), 9-28. doi.org/10.1111/j.1468-2370.2008.00252.x

Love, J. H., Roper, S., 2015. SME innovation, exporting and growth: A review of existing evidence. International Small Business Journal, 33(1), 28-48. doi.org/10.1177/0266242614550190

Lu, J. W., Beamish, P. W., 2006. SME internationalization and performance: Growth vs. profitability. Journal of International Entrepreneurship, 4(1), 27-48. doi.org/10.1007/s10843-006-8000-7

Majocchi, A., Zucchella, A., 2003. Internationalization and performance: Findings from a set of Italian SMEs. International Small Business Journal, 21(3), 249-268. doi.org/10.1177/02662426030213001

Malca, O., Peña-Vinces, J., Acedo, F., 2019. Export promotion programmes as export performance catalysts for SMEs: insights from an emerging economy. Small Business Economics, june, 1-21. doi.org/10.1007/s11187-01900185-2

Mikes, A. 2009. Risk management and calculative cultures. Management Accounting Research, 20(1), 18-40. doi.org/10.1016/j.mar.2008.10.005

Miller, K. D., 1992. A framework for integrated risk management in international business. Journal of International Business Studies, 23(2), 311-331. doi.org/10.1057/palgrave.jibs.8490270

Morgan, N. A., Vorhies, D. W., Schlegelmilch, B. B., 2006. Resource-performance relationships in industrial export ventures: The role of resource inimitability and substitutability. Industrial Marketing Management, 35(5), 621-633. doi.org/10.1016/j.indmarman.2005.05.018

Nason, R. S., Wiklund, J., 2018. An assessment of resource-based theorizing on firm growth and suggestions for the future. Journal of Management, 44(1), 32-60. doi.org/10.1177/0149206315610635

Nocco, B. W., Stulz, R. M. (2006). Enterprise risk management: Theory and practice. Journal of applied corporate finance, 18(4), 8-20. doi.org/10.1111/j.1745-6622.2006.00106.x

Ojala, A., 2009. Internationalization of knowledge-intensive SMEs: The role of network relationships in the entry to a psychically distant market. International Business Review, 18(1), 50-59. doi.org/10.1016/j.ibusrev.2008.10.002

Oviatt, B. M., McDougall, P. P., 1997. Challenges for internationalization process theory: The case of international new ventures. Management International Review, 37, 85-99. www.jstor.org/stable/40228434 
Oviatt, B. M., McDougall, P. P., 2005. Defining international entrepreneurship and modeling the speed of internationalization. Entrepreneurship Theory and Practice, 29(5), 537-553. doi.org/10.1111/j.15406520.2005.00097.x

Oviatt, B.M., Shrader, R.C., McDougall, P.P., 2004. The internationalization of new ventures: a risk management model, in Hitt, M.A. and Cheng, J.L.C. (ed.) "Theories of the Multinational Enterprise: Diversity, Complexity and Relevance" Emerald Group Publishing Limited, 165 - 185. doi.org/10.1016/S0747-7929(04)16009-5

Paape, L., Speklé, R. F., 2012. The adoption and design of enterprise risk management practices: An empirical study. European Accounting Review, 21(3), 533-564. doi.org/10.1080/09638180.2012.661937

Paul, J., Parthasarathy, S., Gupta, P., 2017. Exporting challenges of SMEs: a review and future research agenda. Journal of World Business, 52(3), 327-342. doi.org/10.1016/j.jwb.2017.01.003

Peng, M. W., 2001. The resource-based view and international business. Journal of Management, 27(6), 803-829. doi.org/10.1016/S0149-2063(01)00124-6

Podsakoff, P. M., MacKenzie, S. B., Lee, J. Y., Podsakoff, N. P., 2003. Common method biases in behavioral research: A critical review of the literature and recommended remedies. Journal of Applied Psychology, 88(5), 879. doi.org/10.1037/0021-9010.88.5.879

Power, M., 2009. The risk management of nothing. Accounting, organizations and society, 34(6-7), 849-855. doi.org/10.1016/j.aos.2009.06.001

Rostami, A., Sommerville, J., Wong, I. L., Lee, C., 2015. Risk management implementation in small and medium enterprises in the UK construction industry. Engineering, Construction and Architectural Management, 22(1), 91-107. doi.org/10.1108/ECAM-04-2014-0057

Schweizer, R., Vahlne, J. E., Johanson, J., 2010. Internationalization as an entrepreneurial process. Journal of International Entrepreneurship, 8(4), 343-370. doi.org/10.1007/s10843-010-0064-8

Seringhaus, F.H.R., 1986. The impact of government export marketing assistance. International Marketing Review, 3(2), 55-66. doi.org/10.1108/eb008306

Shrader, R. C., Oviatt, B. M., McDougall, P. P., 2000. How new ventures exploit trade-offs among international risk factors: Lessons for the accelerated internationalization of the 21st century. Academy of Management Journal, 43(6), 1227-1247. doi.org/10.5465/1556347

Silva, E. S., Wu, Y., Ojiako, U., 2013. Developing risk management as a competitive capability. Strategic Change, 22(5-6), 281-294. doi.org/10.1002/jsc. 1940

Sirmon, D. G., Hitt, M. A., Ireland, R. D., Gilbert, B. A., 2011. Resource orchestration to create competitive advantage: Breadth, depth, and life cycle effects. Journal of management, 37(5), 1390-1412. doi.org/10.1177/0149206310385695 Spyropoulou, S., Katsikeas, C. S., Skarmeas, D., Morgan, N. A., 2018. Strategic goal accomplishment in export ventures: the role of capabilities, knowledge, and environment. Journal of the Academy of Marketing Science, 46(1), 109-129. doi.org/10.1007/s11747-017-0519-8

Subramaniam, N., Collier, P., Phang, M., Burke, G., 2011. The effects of perceived business uncertainty, external consultants and risk management on organisational outcomes. Journal of Accounting \& Organizational Change, 7(2), 132-157. doi.org/10.1108/18325911111139671

Verbano, C., Venturini, K., 2013. Managing risks in SMEs: a literature review and research agenda. Journal of Technology Management and Innovation, 8(3), 186-197. doi.org/10.4067/S0718-27242013000400017

Teece, D. J. 2012. Dynamic Capabilities: Routines versus Entrepreneurial Action. Journal of Management Studies, Special Issue: Micro-Origins of Organizational Routines and Capabilities, 49(8), 1395-1401. doi.org/10.1111/j.14676486.2012.01080.x

Wang, X., Chen, A., Wang, H., Li, S., 2017. Effect of export promotion programs on export performance: evidence from manufacturing SMEs. Journal of Business Economics and Management, 18(1), 131-145. https://doi.org/10.3846/16111699.2016.1278031

Wernerfelt, B., 1984. A resource-based view of the firm. Strategic Management Journal, 5, 171-180. doi.org/10.1002/smj.4250050207

Wernerfelt, B., 2011. Invited editorial: The use of resources in resource acquisition. Journal of Management, 37(5), 1369-1373. doi.org/10.1177/0149206310371693

Westhead, P., Wright, M., Ucbasaran, D., 2001. The internationalization of new and small firms: A resource-based view. Journal of Business Venturing, 16(4), 333-358. doi.org/10.1016/S0883-9026(99)00063-4

Wheeler, C., Ibeh, K., Dimitratos, P., 2008. UK export performance research: review and implications. International Small Business Journal, 26(2), 207-239. doi.org/10.1177/0266242607086574

Wilkinson, T., Brouthers, L. E., 2006. Trade promotion and SME export performance. International Business Review, 15(3), 233-252. doi.org/10.1016/j.ibusrev.2006.03.001

Winter, S. G., 2000. The satisficing principle in capability learning. Strategic management journal, 21(10-11), 981996. https://doi.org/10.1002/1097-0266(200010/11)21:10/11<981::AID-SMJ125>3.0.CO;2-4 
Wright, M., Westhead, P., Ucbasaran, D., 2007. Internationalization of small and medium-sized enterprises (SMEs) and international entrepreneurship: A critique and policy implications. Regional Studies, 41(7), $1013-1030$. doi.org/10.1080/00343400601120288

Young, S., Bell, J. and Crick, D., 2000. The Resource-based Perspective and Small Firm Internationalization: An Exploratory Approach, in C. Millar, R. Grant and C. Choi (eds.) International Business: Emerging Issues and Emerging Markets, St Martin's Press: New York. https://doi.org/10.1057/9780230596740_5

Zhou, L., 2007. The effects of entrepreneurial proclivity and foreign market knowledge on early internationalization. Journal of World Business, 42(3), 281-293. doi.org/10.1016/j.jwb.2007.04.009

Zhou, L., Wu, A., Barnes, B. R., 2012. The effects of early internationalization on performance outcomes in young international ventures: the mediating role of marketing capabilities. Journal of International Marketing, 20(4), 25-45. https://doi.org/10.1509/jim.12.0076

\section{Appendices}

Appendix A: Details on the measurement variables

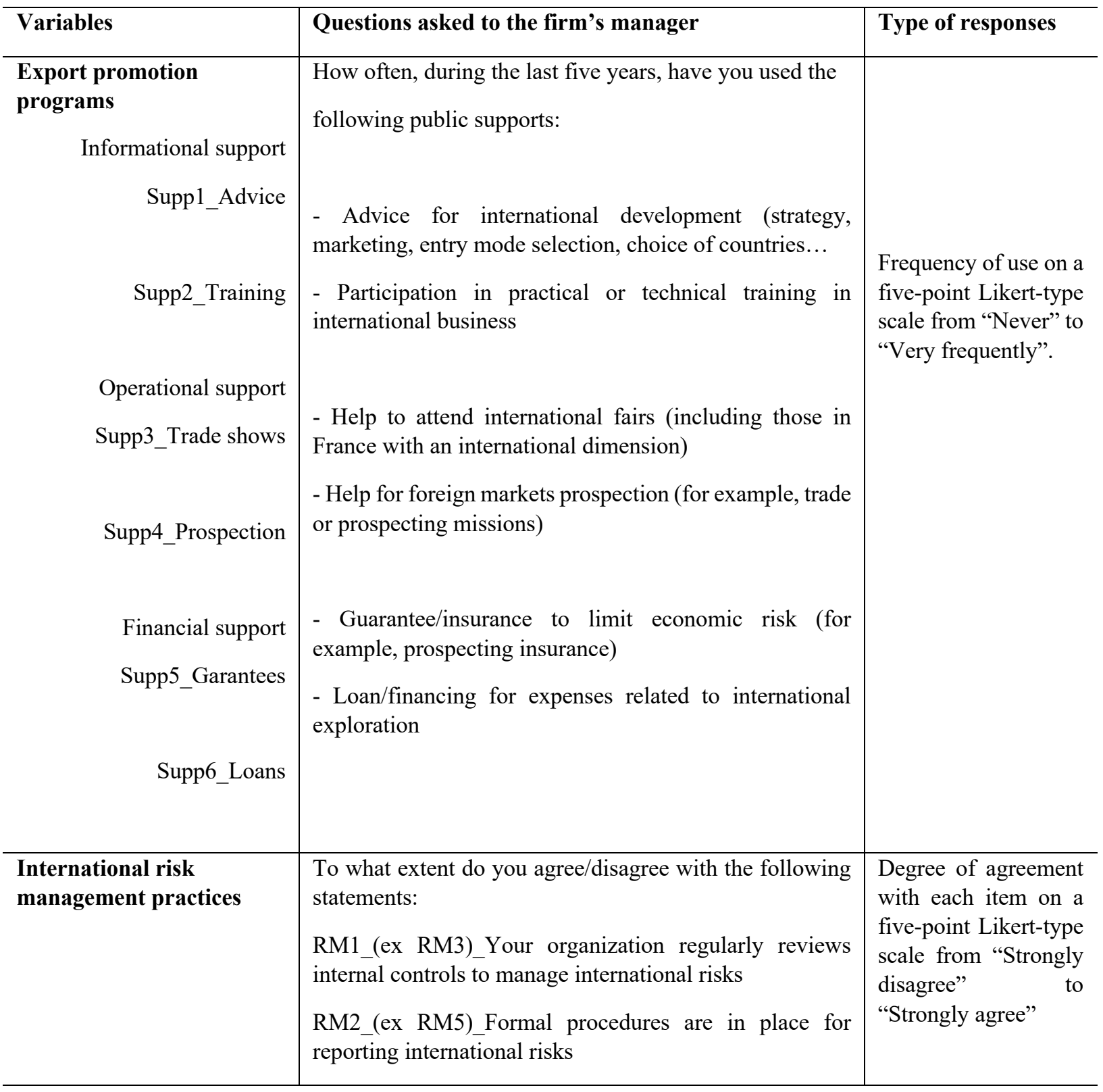




\begin{tabular}{|c|c|c|}
\hline & $\begin{array}{l}\text { RM3_(ex RM8)_Changes to international risks are } \\
\text { addressed and reported on an ongoing basis }\end{array}$ & \\
\hline Export capabilities & $\begin{array}{l}\text { To what extent do you agree/disagree with the following } \\
\text { statements: } \\
\text { CAP1_We have the capability to locate/analyse potential } \\
\text { foreign markets. } \\
\text { CAP2_We have the capability to identifying attractive } \\
\text { foreign business opportunities. } \\
\text { CAP3_We have the capability to contacting prospective } \\
\text { foreign customers. }\end{array}$ & $\begin{array}{l}\text { Degree of agreement } \\
\text { with each item on a } \\
\text { five-point Likert-type } \\
\text { scale from "Strongly } \\
\text { disagree" } \\
\text { "Strongly agree" to }\end{array}$ \\
\hline Export turnover & $\begin{array}{l}\text { What was your percentage of international sales (export } \\
\text { turnover) in } 2018 ? \\
\text { From } 1=\text { " } 1 \text { to } 10 \% " \text { to } 10=\text { "91 to } 100 \% " \text {. }\end{array}$ & $\begin{array}{l}\text { Objectives measures } \\
\text { collected in the } \\
\text { survey }\end{array}$ \\
\hline Foreign direct investment & $\begin{array}{l}\text { The following measure was collected: } \\
\text { Does the firm used foreign direct investments to enter into } \\
\text { foreign markets? }\end{array}$ & $\begin{array}{l}\text { Answer with "Yes" } \\
\text { or "No" }\end{array}$ \\
\hline Competitive intensity & $\begin{array}{l}\text { To what extent do you agree/disagree with the following } \\
\text { statements: } \\
\text { COMP1_Competition in our export market is cutthroat. } \\
\text { COMP2_Anything that one competitor can offer in our } \\
\text { export market, others can match readily. } \\
\text { COMP3_One hears of a new competitive move in our } \\
\text { export markets almost every day. } \\
\text { COMP4_Price competition is a hallmark of our export } \\
\text { market. } \\
\text { COMP5_There are many "promotion wars" in our export } \\
\text { market. }\end{array}$ & $\begin{array}{l}\text { Degree of agreement } \\
\text { with each item on a } \\
\text { five-point Likert-type } \\
\text { scale from "Strongly } \\
\text { disagree" } \\
\text { "Strongly agree" to }\end{array}$ \\
\hline
\end{tabular}

Appendix B: Descriptive statistics and Pearson correlations for the related variables 


$$
\text { 1. EPP }
$$

$$
2 .
$$

$.246^{* *}$

\begin{tabular}{|c|c|c|c|c|c|c|c|c|c|c|c|c|}
\hline 3. EXP_CAP & $.184 *$ & $.418^{* *}$ & & & & & & & & & & \\
\hline 4. FDI & $.352 * *$ & $.396^{* *}$ & $.344 * *$ & & & & & & & & & \\
\hline 5. EXP_TURNOVER & .117 & $.276^{* *}$ & $.481 * *$ & $.278 * *$ & & & & & & & & \\
\hline 6. Comp_intensity & .053 & -.020 & -.094 & .096 & -.090 & & & & & & & \\
\hline 7. Industry & .081 & .071 & .040 & $.182 *$ & $.229 * *$ & .015 & & & & & & \\
\hline 8. Age & -.029 & .004 & -.037 & -.026 & .114 & .049 & $.282 * *$ & & & & & \\
\hline 9. Size & $.319 * *$ & .119 & $.183 *$ & $.303 * *$ & .091 & .044 & .119 & .154 & & & & \\
\hline 10. Int_exp & .075 & .157 & .154 & $.183^{*}$ & $.286^{* *}$ & -.062 & $.247 * *$ & $.693 * *$ & .096 & & & \\
\hline 11. Risk_exposures & $.260 * *$ & $.234 * *$ & $.401 * *$ & $.296 * *$ & $.503 * *$ & -.047 & $.251^{* *}$ & $.163 *$ & $.198 *$ & $.320 * *$ & & \\
\hline 12. Family_firm & .056 & .014 & .044 & -.051 & .011 & .045 & $.234 * *$ & $.240 * *$ & -.142 & $.210^{*}$ & $.174 *$ & \\
\hline Mean & 1.884 & 2.62 & 3.15 & .35 & 4.16 & 2.87 & .72 & 37.23 & 31.02 & 22.99 & .59 & .74 \\
\hline Standard deviation & .78 & 1.19 & 1.07 & .48 & 3.00 & .96 & .45 & 30.21 & 43.60 & 21.83 & .49 & .44 \\
\hline VIF value & 1.29 & 1.36 & 1.47 & 1.57 & 1.65 & 1.06 & 1.01 & 2.34 & 1.31 & 2.32 & 1.43 & 1.20 \\
\hline
\end{tabular}

RISK_MANA_PRAC 